\title{
Power to the People: Does Ownership Type Influence Electricity Service?
}

\author{
Richard T. Boylan Rice University
}

\begin{abstract}
After storm-related power outages, many have recommended municipalizing investor-owned utilities, claiming that profit-making utilities have insufficient incentive to prepare for storms. I provide empirical evidence that municipal utilities spend more on maintenance of their distribution network than investorowned utilities. Nonetheless, I find that storms significantly disrupt electricity consumption in areas served by municipal utilities but do not disrupt areas served by investor-owned utilities. These results are based on a stratified random sample of 241 investor-owned, 96 cooperative, and 94 municipal utilities in the United States between 1999 and 2012. I conclude that municipal utilities' inefficiencies are more important in causing power outages than investor-owned utilities' disincentives to spend on maintenance.
\end{abstract}

\section{Introduction}

In the 1990s, many governments introduced market forces to the electricitygenerating industry. Some countries also privatized electric distribution. For instance, in 1990, all of the electric distribution companies in England and Wales were privatized. Similarly, in Australia, all of the distribution companies in the states of Victoria and South Australia were privatized in 1995 and 2001. In contrast, in the United States the share of residential customers served by government utilities remains unchanged (15 percent in 1990 and 14 percent in 2011). Further, municipal utilities continue to receive a variety of subsidies: federal income tax exemption, federal income tax exemption on debt issued by utilities, and lower prices for federal hydropower. Finally, the press reports calls to municipalize investor-owned utilities rather than calls to privatize municipal utilities (Singer 2012; Cardwell 2013; Bruun 2009; Janoski 2012).

Seminar participants at the fall 2013 University of Houston-Rice University Empirical Microeconomics Seminar Series and the 2014 Berkeley Conference on Empirical Legal Studies, Allan CollardWexler, Peter Hartley, Garth Heutel, Vivian Ho, Sam Peltzman, David Reeb, Alex Whalley, Dennis Carlton, an editor, and a referee provided useful comments. Mark Agerton helped in accessing the Federal Energy Regulatory Commission Form 1 database.

[Journal of Law and Economics, vol. 59 (May 2016)]

(c) 2016 by The University of Chicago. All rights reserved. 0022-2186/2016/5902-0015\$10.00 
One of the main arguments for municipalization is the alleged poor performance of investor-owned utilities after major storms. ${ }^{1}$ Following Hurricane Irene, many customers of investor-owned Connecticut Light and Power were without electricity for 11 days, while customers of municipal utilities in Connecticut experienced only brief power outages (Singer 2012). Similarly, in Massachusetts, municipal utilities in some of the hardest-hit areas were able to restore power in a day or two, while investor-owned utilities like NStar took a week (Cardwell 2013). ${ }^{2}$ The press has argued that these extended outages are due to investor-owned utilities skimping on maintenance to pay higher dividends. For instance, prior to Hurricane Irene, Connecticut Light and Power spent \$78 per customer on maintenance, while the municipal utility in Norwich, Connecticut, spent \$132 (Cox 2011). ${ }^{3}$ However, I am not aware of any empirical analysis that confirms that investor-owned utilities spend less on storm preparedness or are more likely to suffer power outages following storms. I seek to fill this gap by examining whether the mode of ownership of an electric utility affects these quality-of-service measures.

First, I examine storm-preparedness expenditures in a sample of 179 investorowned, 801 cooperative, and 1,437 municipal electric utilities in the United States for 1995-2002. Most discussion about storm preparedness has focused on maintaining electric distribution lines (for example, regularly cutting tree branches near power lines) and burying power lines underground. I find that, per line mile, municipal utilities spend more on maintaining their distribution network than investor-owned utilities. However, the higher expenditures by municipal utilities could indicate greater inefficiency rather than greater storm preparedness. For instance, a variety of studies find increasing returns to electric distribution up to at least 20,000 customers (Salvanes and Tjøtta 1994; Yatchew 2000; Growitsch, Jamasb, and Pollitt 2009). Many municipal utilities cannot take advantage of these economies of scale because a variety of institutional factors lead them to be too small. ${ }^{4}$ In my expenditure sample, 9 percent of municipal utilities have more

\footnotetext{
${ }^{1}$ The other goals for advocates of municipalization are lowering electricity rates and using more renewable energy.

${ }^{2}$ In addition, when northern New York was ravaged by an ice storm in 1998, customers of the municipally owned Massena Electric restored power after 2 days, while customers of neighboring communities served by investor-owned National Grid were in the dark for 3 weeks (Bruun 2009). Customers of Butler Power and Light, a municipally owned utility in New Jersey, had better electricity service after Superstorm Sandy in 2012 than customers of neighboring towns that were served by the investor-owned Jersey Central Power and Light (Janoski 2012). In 2003, residents of White Park, Florida, municipalized their electrical service in response to frequent power outages (Sigo 2003). The city of South Daytona, Florida, attempted to municipalize electrical service to ensure more frequent tree trimming around lines and quicker responses by repair crews after major storms. However, in 2013, voters rejected the measure (Weiss 2013).

${ }^{3}$ Similarly, NStar had 3.08 line technicians per 10,000 residents, while Massachusetts's municipal utilities averaged 3.8 per 10,000 residents (Van Voorhis 2012).

${ }^{4}$ An example of an institutional factor that ensures that municipal utilities remain small is the federal law that prohibits the use of tax-exempt municipal bonds to finance the purchase of electricpower-generating facilities from private utilities (Jones 1989). Another example is Federal Energy Regulatory Commission Order 888 (18 C.F.R. pts. 35 and 385 [1996]). Under this order, investor-
} 
than 20,000 residential customers, versus 82 percent of investor-owned utilities. ${ }^{5}$ Further, I find that municipal utilities have a smaller fraction of their distribution networks underground. Thus, I cannot conclude that municipal utilities are better prepared for storms by solely examining maintenance expenditures.

Second, I examine the effect of ownership type on storm-related outages, where I proxy for outages using the percentage difference between one month's electricity consumption and electricity consumption in the same month of the prior year. For my proxy for outages, I have a stratified random sample of 241 investor-owned, 96 cooperative, and 94 municipal utilities in the United States between 1999 and 2012. I find that storms with damages (destruction of private and public property) that equal 1 percent of personal income lead to a 1.85 percent decrease in residential electricity consumption by municipal utilities but have no effect on consumption by investor-owned utilities.

These results suggest that privatizing municipal utilities would result in savings in federal subsidies and maintenance expenditures while preserving the quality of service following storms. These conclusions are consistent with prior international experiences. There were fewer outages following the privatization of electric distribution in Argentina (Gonzalez-Eiras and Rossi 2007) and in the state of Victoria in Australia (Hartley 1999), while the privatization of electric distribution in Italy did not lead to an increase in power outages (Fumagalli, Garrone, and Grilli 2007). However, I am not aware of any work that examines the effect of ownership type on storm preparedness in the United States. ${ }^{6}$

Section 2 provides an empirical framework and discusses potential threats to identification. Section 3 describes the data and provides summary statistics by ownership type. Section 4 presents the results, and Section 5 concludes.

\section{Empirical Framework}

I estimate two regressions. The first examines the effect of a utility's ownership type on spending on its distribution network, and the second examines the effect of a utility's ownership type on storm-related changes in power usage.

owned utilities must be compensated for stranded costs, the losses in revenues to the utility that result from municipalization (Doane and Spulber 1997).

${ }^{5}$ There are many other reasons to expect municipal utilities to operate inefficiently. For instance, I expect managers of municipal utilities to have lower personal incentives to minimize costs (Hart, Shleifer, and Vishny 1997) and to have to respond to short-term electoral pressures (Levitt 1997; Vlaicu and Whalley 2013).

${ }^{6}$ Studies of the United States have found that, compared with municipal electric utilities, investorowned utilities charge higher prices (Peltzman 1971; Kwoka 2002) but adopt new technologies earlier (Rose and Joskow 1990). There is also work examining the effect of regulation of investor-owned utilities on outages. Hausman (2014) finds that deregulation leads to fewer unplanned power outages at nuclear power plants. Ter-Martirosyan and Kwoka (2010) find that regulatory provisions that provide incentives for low costs increase the length of power outages, while those that provide incentives for quality reduce the length of power outages. Lim and Yurukoglu (2014) find that there are fewer outages in states where a higher proportion of public utility commissioners are Republican. 


\subsection{Effect of Ownership on Spending on the Distribution Network}

In the first regression, the unit of observation is a utility $u$. The effect of a utility's ownership type on spending on its distribution network is measured in the following cross-sectional regressions:

$$
\ln e_{u}=\alpha^{1 e}+\alpha_{s(u)}^{2 e}+\alpha_{o(u)}^{3 e}+\beta^{e} \boldsymbol{X}_{u}
$$

and

$$
p_{u}=\alpha^{1 p}+\alpha_{s(u)}^{2 p}+\alpha_{o(u)}^{3 p}+\beta^{p} \boldsymbol{X}_{u},
$$

where $e_{u}$ is utility $u$ 's distribution operations and maintenance expenditures per distribution line mile and $p_{u}$ is the percentage of distribution lines underground. The variable $o(u)$ denotes the mode of ownership of utility $u$ : investor owned, municipal, or cooperative. The variable $s(u)$ is the state where the utility has most of its residential customers. Finally, $\boldsymbol{X}_{u}$ is a vector of controls.

\subsection{Effect of Ownership on Storm-Related Changes in Power Usage}

In the second regression, the unit of observation is a utility $u$ operating in state $s$, year $y$, and month $t$. To estimate the effect of ownership type on storm-related changes in power usage, I estimate the following panel regression:

$$
\Delta \ln q_{u s y t}=\alpha_{y}^{1}+\alpha_{s}^{2}+\alpha_{o(u)}^{3}+\sum_{m=h}^{k} \beta_{o(u)}^{m} \Delta \text { Damages }_{u s y t-m}+\gamma_{s} \Delta \ln d_{u s y t} .
$$

The dependent variable $q_{\text {usyt }}$ is residential electricity consumption, and $\Delta$ denotes the difference between the current month's value of $q$ and the prior year's value of $q$; that is, $\Delta \ln q_{\text {usyt }}=\ln q_{\text {usyt }}-\ln q_{\text {usyt-1t }}$. There are two reasons for estimating the regression in long differences. First, the dependent variables are potentially seasonal. Thus, by eliminating seasonality, I reduce the errors in the dependent variables. Second, in many states, large storms tend to occur during months when electricity consumption is the highest. Thus, seasonal effects are potential sources of endogeneity.

In the more general version of the regression, I allow damages to have contemporaneous $(m=0)$, lagged $(m>0)$, and lead effects $(m<0)$. The main explanatory variable, Damages usyt-m , is the sum of storm damages (destruction of private and public property) during year $y$, month $t-m$, over all the counties served by utility $u$ in state $s$. Damages are measured as a percentage of yearly personal income over the same counties. Thus, Damages equals one if damages are 1 percent of personal income. The primary coefficient of interest, $\beta_{o(u)}^{m}$, is the interaction of mode of ownership and storm damages that occurred $m$ months prior. For instance, if $\beta_{1}^{\text {Public }}=-2$, then damages equaling 1 percent of personal income lead to a 2 percent reduction in residential electricity consumption by municipal utilities 1 month after the storm.

The scalars $\alpha_{y}^{1}, \alpha_{s}^{2}$, and $\alpha_{o(u)}^{3}$ denote year, state, and mode of ownership fixed 
effects. The variable $d_{\text {usyt }}$ denotes the sum of heating degree days and cooling degree days, two variables commonly used to predict electricity consumption. I allow the impact of degree days on the dependent variable $\gamma_{s}$ to vary by state.

I provide an illustration of my findings by estimating equation (1) with current damages, one lead, and one lag, that is, with $h=-1$ and $k=1$. To simplify the tables, I estimate the effect of the sum of the current and prior month's storm damages. In other words, I set $h=0, k=1$, and $\beta_{o(u)}^{0}=\beta_{o(u)}^{1}=\beta_{o(u)}$ and estimate

$$
\Delta \ln q_{u s y t}=\alpha_{y}^{1}+\alpha_{s}^{2}+\alpha_{o(u)}^{3}+\beta_{o(u)}+\sum_{m=0}^{1} \Delta \text { Damages }_{u s y t-m}+\gamma_{s} \Delta \ln d_{u s y t} .
$$

\subsection{Potential Threats to Identification}

For the regressions with expenditures, one may be concerned that municipal utilities are more likely to face storms that are potentially damaging to electrical service. This positive correlation would arise if municipal utilities cover areas that cannot be served profitably by investor-owned utilities because of frequent storm damages to utilities. Thus, one could hypothesize that municipal utilities have to spend more on maintenance of their distribution networks because they have to be more prepared for future storms or for an incoming storm. Institutional factors make it unlikely that ownership type is strongly correlated with current storm damages, because ownership type is difficult to change, and ownership type of many utilities dates back to the 1940s. ${ }^{7}$ While storm damages may have influenced ownership type in the 1940s, I expect technological and population changes to have altered the susceptibility of electrical systems to suffer storm-related outages. ${ }^{8}$ Thus, it is conceivable that current ownership type is more strongly correlated with county characteristics that made storms damaging 70 years ago than with current characteristics. Nonetheless, I check the robustness of the results by including variables for damages to private and public property in two time periods: 1994-2002 and 2003-12.

It is also possible that municipal utilities are concentrated in states with different weather patterns or labor costs for historical reasons. Figure 1 presents the counties in the contiguous United States served by the utilities in the expenditure sample. Municipal utilities are overrepresented in Nebraska, Tennessee, and

${ }^{7}$ Among the 182 electric utility acquisitions recorded in Platts (2006) for 1985-2007, only four involved a municipality acquiring an investor-owned utility, and none involved an investor-owned utility acquiring a municipal utility. An example of an institutional factor that makes changes in ownership type difficult is a Connecticut law that sets the following requirements for creating a municipal utility: a two-thirds vote of the municipality's legislative body, approval of its chief executive, and approval of the voters at a referendum (McCarthy and Hansen 2012). Another institutional factor is public employees' labor unions' opposition to privatization of municipal utilities, presumably for fear of loss of employment and pensions (Beecher, Dreese, and Stanford 1995; Lopez-de-Silanes, Shleifer, and Vishny 1997).

${ }^{8}$ Further, politics was a big factor in determining their original ownership type. For instance, many municipal utilities were established around the turn of the 19th century as a means of combating corruption in cities (Schap 1986; Glaeser 2004), while electric cooperatives are the product of the New Deal. 
Washington State. I account for this geographic concentration by including state fixed effects in the regressions.

For the regression examining power usage, there are four possible threats to identification. The first is the concern that municipal utilities are less likely to face damaging storms. If this is the case, I may expect municipal utilities to be less prepared for storms and hence to experience greater disruptions when faced with a major storm. I attempt to mitigate this problem by excluding from the sample utilities located in areas that have suffered high levels of storm-related damages. I also reestimate the regression excluding the observations of one state, one state at a time.

A second potential threat to identification arises from the concern that my measure of damages does not capture damages to electric utilities. The reason for this is that my measure of damages includes destruction to all personal and public property, and destruction of property belonging to electric utilities is likely to be a small fraction of the total. Further, a variety of factors influence the size of this fraction. In rural areas, electrical circuits are long and more exposed to a variety of factors that can lead to outages (Kaufmann et al. 2010). Alternatively, the same wind speeds may result in different levels of monetary damages to private and public property, depending on whether the county is urban, rural, poor, or rich. I try to account for these possibilities by controlling for factors such as the nature of the storm, population density, income, and the value of houses.

A third potential threat to identification relates to the concern that the reduction in electricity consumption after a storm results from a change in demand rather than a change in supply. ${ }^{9}$ For instance, if areas served by municipal utilities are more likely to have mass evacuations in anticipation of storms, then the reduction in the demand for electricity is greater for municipal than for investor-owned utilities. I address this concern in two ways. First, differences in demand may be due to differences in observable characteristics. Thus, these demand effects are controlled for by including additional variables in the regression: damages caused by tropical storms and the interaction of damages with income per capita, population density, and the value of houses. Second, I reestimate equation (2) with retail sales and employment as the dependent variables. If changes in electricity demand caused by a storm differ by utility ownership type, then I would also expect changes in employment and retail sales caused by a storm to differ by ownership type. Conversely, if I find small ownership-type differences in the impact of storms on employment and retail sales, it is unlikely that my findings result from ownership-type differences in changes in the demand for electricity.

A fourth potential threat to identification arises from the concern that changes

\footnotetext{
${ }^{9}$ I expect changes in the demand for electricity because prior studies show that hurricanes have short-term effects on the local economy. Belasen and Polachek (2009) find that Florida counties hit by hurricanes experience short-term increases in wages and decreases in employment, while Strobl (2011) finds that in response to hurricanes, coastal counties experience short-term decreases in personal income.
} 


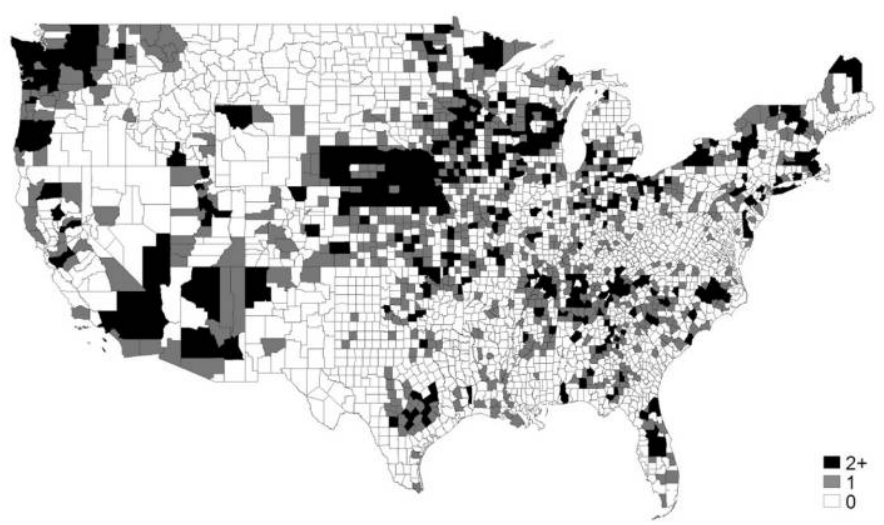

Municipal

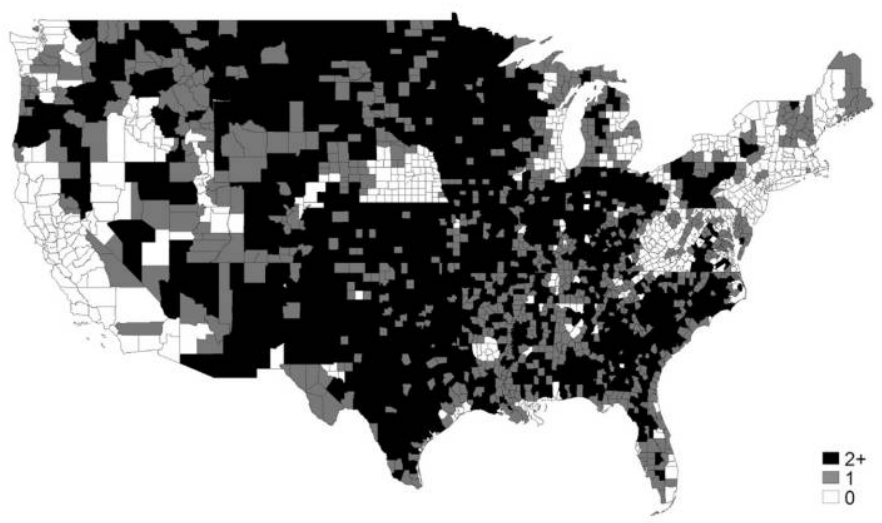

Cooperative

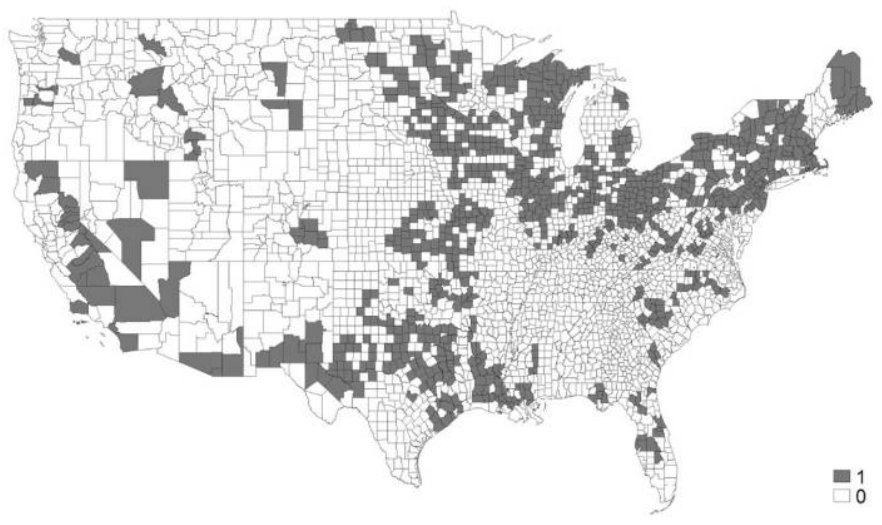

Investor Owned

Figure 1. Number of electric utilities

This content downloaded from 128.042.192.107 on May 01, 2017 10:22:08 AM

All use subject to University of Chicago Press Terms and Conditions (http://www.journals.uchicago.edu/t-and-c). 
in power usage are a poor proxy for outages. In Section 3.2, I provide statistical evidence that power outages are correlated with changes in monthly consumption. More importantly, measurement error in a dependent variable is a source of bias only if it is related to the explanatory variable. For instance, I might expect industrial power plants to have to compensate for any losses in production during an outage. If this is the case, and if investor-owned utilities sell a greater fraction of their power to industrial power plants, then measurement error is correlated with ownership type, and the estimates will be biased. I attempt to control for this by separating residential from nonresidential electricity consumption.

\section{Data, Samples, and Summary Statistics}

\subsection{Expenditure Data}

I examine operations and maintenance expenditures on distribution networks, which comprise the wiring of electricity from electrical substations to customers (generally in lines below $35 \mathrm{kV}$ ). ${ }^{10}$ For investor-owned utilities and a few cooperatives, data on distribution expenditures are from Federal Energy Regulatory Commission Form 1, Electric Utility Annual Report. ${ }^{11}$ Operations expenditures include the cost of changing line transformer taps, performing load tests of line transformers, and adjusting line-testing equipment. Maintenance expenditures include the costs of straightening poles, trimming trees, and clearing brush (see Uniform System of Accounts Prescribed for Public Utilities and Licensees Subject to the Provisions of the Federal Power Act, 18 C.F.R. pt. 101). For municipal utilities, expenditure data are from the Energy Information Administration's Form EIA-412, Annual Electric Industry Financial Report. ${ }^{12}$ Giles and Hayes (1999) provide the length of the distribution system (overhead and underground) and additional data on distribution expenditures.

\subsection{Power Usage Data}

There are three potential sources for outage data. The Department of Energy's Form OE-417, Electric Emergency Incident and Disturbance Report, should collect instances of all significant power outages, and data from the reports thus would seem to provide an ideal proxy for storm-related outages. ${ }^{13}$ However, utilities are required to report only losses of electrical service that affect more than 50,000 customers. Since investor-owned utilities are much larger than municipal utilities, they are much more likely to have to report a power outage. For instance, in 2011, only 2 percent of municipal utilities had more than 50,000 customers,

${ }^{10}$ In contrast, transmission networks comprise the wiring of electricity from power plants or grids to electrical substations (generally in lines above $69 \mathrm{kV}$ ).

${ }^{11}$ See Federal Energy Regulatory Commission, Form 1-Electric Utility Annual Report: Data (Current and Historical) (https://www.ferc.gov/docs-filing/forms/form-1/data.asp).

${ }^{12}$ See Energy Information Administration, Form EIA-412 Archive Data (https://www.eia.gov /electricity/data/eia412/).

${ }^{13}$ See Department of Energy, Electric Disturbance Events (OE-417) Annual Summaries (https:// www.oe.netl.doe.gov/OE417_annual_summary.aspx). 
versus 54 percent of investor-owned utilities. Thus, these data are a biased measure of which mode of ownership is more likely to experience power outages.

I can, however, use the Form OE-417 data to provide evidence of the importance of storm-related outages. I examine the 2003-12 Form OE-417 events, excluding outages that affected fewer than 500 customers and for which I could not identify the affected utilities. I group the source of outage into hurricane, winter weather, other weather, or not weather related (breaker failures, fires, earthquakes, electrical system separation, generation inadequacy, load shedding, transmission equipment failure, and vandalism). For each type of outage, I use the average values for the number of customers affected and the duration. I compute the percentage of customers affected as (number of customers affected)/ (total number of residential customers), where the number of residential customers served by a utility is from Form EIA-861 data (discussed below). The summary statistics reported in Table 1 show that 37 percent of outages are weather related, which tend to affect more customers and be of longer duration.

Other sources of outage data are state utility commissions. These data were used to study the reliability of investor-owned utilities' service by Ter-Martirosyan and Kwoka (2010) and Lim and Yurukoglu (2014). However, state utility commissions do not usually collect outage data for municipal utilities and cooperatives, and thus I cannot use them to examine the impact of mode of ownership on outages.

Instead, I proxy outages by changes in monthly electricity consumption for a stratified sample of utilities surveyed by the Energy Information Administration. ${ }^{14}$ This survey, the Monthly Electric Utility Sales and Revenue Report with State Distributions (compiled from Form EIA-826), provides residential consumption (in megawatts), nonresidential consumption (in megawatts), and the number of residential customers. I also include 204 additional observations from the Florida Public Service Commission's Statistics of the Florida Electric Utility Industry (1999-2011).

My proxy for outages is the percentage difference between a month's residential electricity consumption and residential electricity consumption the same month of the prior year. ${ }^{15}$ As mentioned in the Introduction, customers of NStar suffered power outages after Hurricane Irene hit Massachusetts on August 27, 2011. My data report that NStar sold 527,532 MW to residential customers in August 2011, compared with 557,290 in August 2010 and 548,929 in August 2012. Thus, the power outage was associated with a $(557,290-527,532) / 557,290$ $=5$ percent decrease in electricity consumption.

There are two advantages to this proxy for power outages. First, the proper functioning of the electric grid requires balancing flows of electricity generated

\footnotetext{
14 The random-sampling procedure ensures coverage of all states and the District of Columbia and oversamples larger utilities.

${ }^{15}$ More precisely, the proxy is the difference between the log of a month's residential electricity consumption and the log of the previous year's electricity consumption.
} 
Table 1

Summary Statistics for Outages, 2003-12

\begin{tabular}{lccc}
\hline Outage Type & Events & $\begin{array}{c}\text { Customers } \\
\text { Affected (\%) }\end{array}$ & $\begin{array}{c}\text { Duration } \\
\text { (Hours) }\end{array}$ \\
\hline Hurricane & 210 & 40 & 106 \\
Winter weather & 203 & 21 & 86 \\
Other weather & 222 & 22 & 83 \\
Nonweather & 1,095 & 24 & 67 \\
\hline
\end{tabular}

Data sources. Department of Energy, Electric Disturbance Events (OE-417) Annual Summaries (https://www.oe.netl.doe.gov/OE417_annual_summary.aspx); Energy Information Administration, Electric Power Sales, Revenue, and Energy Efficiency Form EIA-861 Detailed Data Files (https://www.eia.gov/electricity/data /eia861/).

Note. Events that affected fewer than 500 customers and events for which the affected utilities could not be identified are excluded.

and sold. ${ }^{16}$ Thus, I expect reported electricity consumption to be highly accurate. ${ }^{17}$ Second, electricity consumption is available for all modes of ownership.

The Form OE-417 data provide some support for my proxy for outages, since reports of outages are correlated with changes in electricity consumption. In the 46 observations in which utilities reported weather-related outages that affected at least 10 percent of monthly residential customer hours, monthly residential electricity consumption decreased by 1.62 percent. In the 789 months when a utility had outages that affected less than 10 percent of monthly residential customer hours, residential electricity consumption increased by .56 percent. ${ }^{18}$ In the 46,822 months when a utility did not report any outages, residential electricity consumption increased by 1.82 percent.

As discussed in Section 2, it is important that the analysis be in long differences to account for seasonality of residential electricity consumption and the fact that seasonality varies by state. This is shown in Figure 2, which presents average monthly residential consumption for Florida and North Dakota for 1990-2012. In Florida, electricity consumption peaks during the summer when air conditioning is used most intensively, while in North Dakota, electricity consumption peaks in the winter when heating is used most intensively.

${ }^{16}$ One way to see this is to look at Electric Information Agency (2013), where table 1.3 provides total energy generated, lost, and exported from a survey of power plant operators (EIA-923), and table 2.2 provides total consumption from a survey of the power industry (EIA-861). By comparing the two tables, I can verify that consumption = generation - losses - exports.

${ }^{17}$ As discussed in Section 5.2, there is still error in my proxy because, for confidentiality reasons, the Electric Information Agency does not release information about electricity purchased from power marketers by utility and month.

${ }^{18}$ There are two reasons why the number of observations with outages reported in this section is different than in Table 1. First, outages included in Table 1 can affect multiple utilities. In this case, to relate outages to changes in monthly electricity consumption, I allocate outages to each utility in proportion to the number of residential customers. Second, in this section I include only outages for which I had data on monthly electricity consumption. 


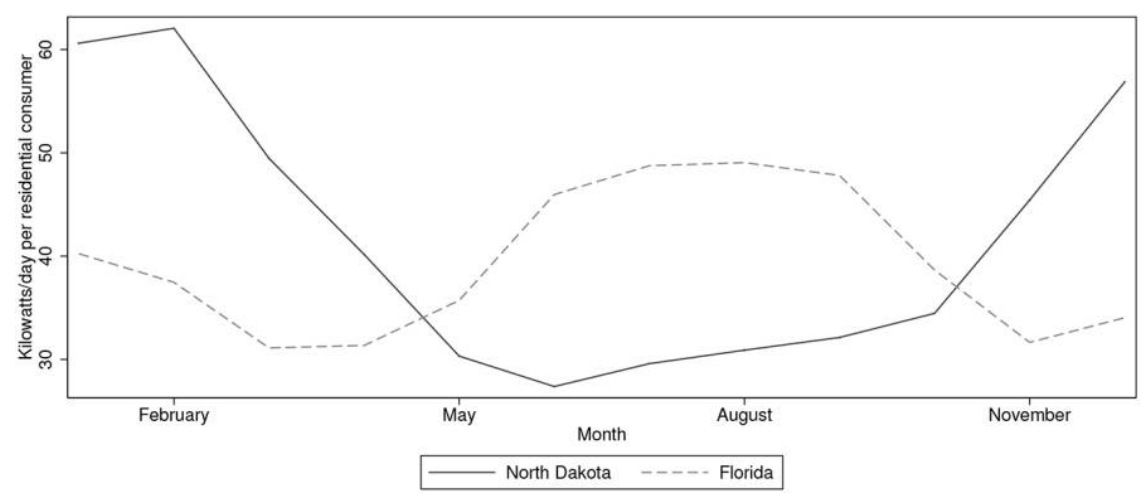

Figure 2. Average residential consumption, 1990-2012

\subsection{Data on Storm Events}

Information on storm events is from the National Oceanic and Atmospheric Administration National Climatic Data Center's Storm Event Database (National Oceanic and Atmospheric Administration 2014). I examine storms from 1996 onward since for prior years the database includes only tornado, thunderstorm wind, and hail events. ${ }^{19}$

Damages refer to the destruction of private property (structures, objects, and vegetation), public infrastructure, and public facilities. National weather officers obtain this information from insurance companies, emergency managers, the Geological Survey, the Army Corps of Engineers, power utility companies, newspaper articles, and other sources (National Weather Service 2007). The Storm Event Database includes 393,862 hurricanes, tornadoes, thunderstorms, floods, lightning, and winter weather events. Table 2 lists summary statistics for these events. The two types of events with the highest per capita damages are tornadoes with F-scale ratings ${ }^{20}$ higher than 2 and hurricanes (property damages of $\$ 315$ and $\$ 590$ per capita, respectively).

One potential problem with the storm data is the arbitrariness in labeling events. For instance, Downton, Miller, and Pielke (2005) point out that the National Oceanic and Atmospheric Administration does not report the \$520 million in flood damages in Massachusetts for February 1978 (the \$520 million figure is from an Army Corps of Engineers' report). In fact, the National Oceanic and Atmospheric Administration does report this event but lists it as a blizzard (with damages of \$50-\$500 million; see National Oceanic and Atmospheric Ad-

\footnotetext{
${ }^{19}$ Another potential source of data is the Spatial Hazards Events and Losses Database for the United States (SHELDUS). The authors of this database collected storm damages prior to 1996 from the National Oceanic and Atmospheric Administration (1978), which uses storm damage categories; for instance, one category represents damages of $\$ 500$ million $-\$ 5$ billion. Thus, property damages before 1996 are not easily comparable to property damages in later years.

${ }^{20}$ Tornado strength is measured according to the Fujita tornado damage scale.
} 
Table 2

Summary Statistics for Storm Events

\begin{tabular}{|c|c|c|c|c|}
\hline \multirow[b]{2}{*}{ Event Type } & \multirow[b]{2}{*}{ Events } & \multirow{2}{*}{$\begin{array}{c}\text { Population } \\
\text { per Event }\end{array}$} & \multicolumn{2}{|c|}{ Damages (\$Millions) } \\
\hline & & & Total & Per Capita \\
\hline Tropical cyclone & 5,443 & 175,247 & 163,877 & 171.80 \\
\hline Hurricane & 1,191 & 133,105 & 93,434 & 589.39 \\
\hline Tornado & 21,156 & 113,061 & 26,621 & 11.13 \\
\hline F-scale $>2$ & 780 & 77,303 & 18,967 & 314.56 \\
\hline Winter weather & 91,867 & 92,417 & 9,152 & 1.08 \\
\hline Flood & 30,927 & 167,869 & 170,336 & 32.81 \\
\hline Thunderstorm & 261,609 & 156,478 & 18,396 & .45 \\
\hline Wind $>80 \mathrm{mph}$ & 9,960 & 178,996 & 8,143 & 4.57 \\
\hline Lightning & 11,488 & 327,706 & 796 & .21 \\
\hline
\end{tabular}

Data source. National Oceanic and Atmospheric Administration (2014).

Note. Tornado strength is measured according to the Fujita tornado damage scale.

ministration 1978). In the main specifications, I resolve the arbitrariness of the labeling of storm events by aggregating damages across all types of storm.

Again, I can use the Form OE-417 data to provide some support for my proxy for damages. In the 59 observations in which utilities reported weather-related outages that affected at least 10 percent of monthly residential customer hours, the area covered by the utility suffered monthly damages equal to .77 percent of personal income. In the 1,035 observations in which a utility reported outages that affected less than 10 percent of monthly residential customer hours, the area suffered monthly damages equal to .37 percent of personal income. ${ }^{21}$ In the 376,138 observations in which a utility did not report any outages, the area suffered monthly damages equal to .02 percent.

\subsection{Other Data}

I obtain mode of ownership, the percentage of electricity that is self-generated, and the list of counties covered by each utility from a yearly survey conducted by the Energy Information Administration (compiled from Form EIA-861, Annual Electric Power Industry Report). ${ }^{22}$ Yearly personal income and midyear population estimates for each county are from the Department of Commerce's Bureau of Economic Analysis. I lag these numbers by 1 year; thus, for 2012, I use the population for 2011. The average value of a detached house is from the 2000 census.

Heating degree days and cooling degree days measure how far temperatures are from 65 degrees Fahrenheit; these data are from the National Climatic Data

\footnotetext{
${ }^{21}$ The number of observations with outages reported in this section is larger than in Table 1 because some outages included in Table 1 affected multiple utilities.

${ }^{22}$ Energy Information Administration, Electric Power Sales, Revenue, and Energy Efficiency Form EIA-861 Detailed Data Files (https://www.eia.gov/electricity/data/eia861/).
} 
Center for each weather station and month. ${ }^{23}$ I use the ZIP code of each weather station to aggregate the data at the county level, using as weights the ratio of all county addresses that are located in a particular ZIP code. ${ }^{24}$ Moreover, the county weather data are aggregated at the utility level, using county population numbers as weights. Finally, heating and cooling degree days are computed by summing heating degree days and cooling degree days.

Sources for data on retail sales are listed in the Appendix; for most states, I use taxable sales as a proxy for retail sales. Employment statistics are from the Bureau of Labor Statistics. ${ }^{25}$ Information about which electric utilities were supervised by the state regulatory agency in 1990 is from Rodgers and Bauer (1991).

\subsection{Aggregation of County-Level Data}

All county-level variables are aggregated at the level of the utility using the information for the counties served by each utility. However, the aggregation is done differently in the expenditure and the power usage samples (that is, the monthly electrical consumption).

For the expenditure sample, since the data are a cross section, I use the information for the counties that are served by a utility in 2000. For example, to compute the population in the area served by a utility, I add the populations of all the counties it served in 2000. When computing damages for 1994-2002, I add the damages for all hurricanes, tornadoes, thunderstorms, lightning, and winter weather events (ice storm, wintry mix, and so forth) for 1994-2002 in the counties served by the utility in 2000 . Since I want to measure whether a utility serves an area that is prone to storm damages, I examine past storm damages in the area, regardless of whether that utility covered it in the past.

For the outage sample, since the data set is a panel, I use the information for the counties that are served by a utility for each year. For example, to compute damages in December 2006, I add damages for all storm events in that month in counties served by the utility in 2006. Since the regression is in first differences, my measure of damages for December 2006 is the difference between damages in December 2006 and in December 2005. Thus, to ensure comparability in damages, I eliminate from the sample observations in years when a utility changed the area it covered.

\footnotetext{
${ }^{23}$ The minimum and maximum temperatures are collected for each weather station and day (see National Oceanic and Atmospheric Administration, Climate Data Online [http://www.ncdc.noaa .gov/cdo-web/search]). Then, heating degrees for a particular day $=\max \{0,65-(\min +\max ) / 2\}$, and cooling degrees for a particular day $=\max \{0,(\min +\max ) / 2-65\}$. Heating degree and cooling degree days for each station and month are computed by averaging heating degrees and cooling degrees for all the days of the month.

${ }^{24}$ See US Department of Housing and Urban Development, HUD USPS ZIP Code Crosswalk Files (http://www.huduser.org/portal/datasets/usps_crosswalk.html).

${ }^{25}$ See Bureau of Labor Statistics, Local Area Unemployment Statistics (ftp://ftp.bls.gov/pub/time series/la/).
} 


\subsection{Samples}

The expenditure sample consists of 179 investor-owned utilities, 801 cooperatives, and 1,437 municipal utilities for which I could obtain the length of distribution lines. Expenditure data are quite noisy, and I was not able to obtain them for all years. To minimize the error, I average real distribution expenditures over 1995-2002. Nonetheless, the number of utilities for which I have distribution expenditures is substantially smaller and consists of 149 investor-owned utilities, 447 cooperatives, and 600 municipal utilities. ${ }^{26}$

Starting in 1999, the Form EIA-861 data include the list of counties covered by each utility. For this reason, I restrict the power usage sample to 1999-2012. I exclude the only federal utility from the data set (the Bureau of Indian Affairs' Mission Power) and combine utilities owned by municipalities, states, and political subdivisions. Further, I exclude utilities that cover areas that had unusually high levels of storm damages during 1996-98, although my main findings hold if I do not exclude them.

Thus, my sample consists of 241 investor-owned utilities, 96 cooperatives, and 94 municipal utilities. ${ }^{27}$ If a utility changes ownership type over the sample, it is considered a different utility. ${ }^{28}$ In the power usage sample, I define utilities as firms operating in a single state. Thus, a utility that operates in three states is counted as three utilities. ${ }^{29}$ The unit of observation is a utility-year-month. Since the sample is from 1999 to 2012 , each utility has at most $14 \times 12=168$ observations. The sample size is, however, reduced because I have a stratified sample, and thus not all utilities are observed in all years. I end up with 31,659 observations from investor-owned utilities, 13,282 from cooperatives, and 13,474 from municipal utilities.

In the regressions, my sample is further reduced to account for a variety of sources of measurement error. I lose the first year of observations for each utility, since I estimate the regressions in long differences to account for seasonal effects. Another source of measurement error is changes in the counties served by a utility. I eliminate this measurement error by excluding the years when a utility just changed county coverage.

\footnotetext{
${ }^{26}$ Thus, the cross-sectional expenditure sample is really two samples: a sample for which there are data on the length of the distribution lines and a subsample for which there are data on expenditures. Fortunately, the ownership-type shares are roughly similar for the full sample and the subsample: for the full sample, the muncipally owned and investor-owned shares are 59 percent and 7.4 percent, respectively, while for the subsample, the municipally owned and investor-owned shares are 50 percent and 12.5 percent.

${ }^{27}$ I end up with a higher percentage of investor-owned utilities in the power usage sample because the stratified sample oversamples larger utilities.

${ }^{28}$ Three utilities for which I have monthly data changed ownership type over the sample: Kaui Island Utility Cooperative purchased the Hawaii division of Citizen Communications Company, Vermont Electric Cooperative purchased the Vermont division of Citizen Communications Company, and A\&N Electric Cooperative purchased the distribution portion of the Delmarva Power Company.

${ }^{29}$ A total of 5.6 percent of municipal utilities, 21.4 percent of investor-owned utilities, and 26.8 percent of cooperative utilities operate in more than one state.
} 
Consumption of electricity purchased from power marketers leads to an additional source of measurement error. For confidentiality reasons, monthly electricity consumption statistics released to the public do not include electricity purchased from power marketers or the number of customers served with electricity purchased from power marketers. Thus, an increase in the use of electricity from power marketers leads to a decrease in reported monthly electricity consumption. I reduce this measurement error in two ways. First, because an increase in consumption of electricity purchased from power marketers decreases both residential electricity sales and the number of residential customers, I reduce the measurement error by examining residential electricity consumption per customer. Second, the Form EIA-861 data provide yearly electricity consumption purchased from power marketers, so I reduce the error in reported monthly electricity sales by excluding all utilities-states-years in which the percentage of customers that receive electricity purchased from power marketers changed by more than 10 percent compared with the previous year.

\subsection{Summary Statistics}

Table 3 provides summary statistics for the expenditure sample by ownership type. Investor-owned utilities are by far the largest utility type, and municipal utilities are the smallest. A few studies estimate returns to scale in distribution of electricity. Using electric distribution data for Norway and Canada, Salvanes and Tjøtta (1994) and Yatchew (2000) find economies of scale for up to 20,000 customers, while using electric distribution data for seven European countries, Growitsch, Jamasb, and Pollitt (2009) find economies of scale throughout the sample. In the full sample, 82 percent of investor-owned utilities have more than 20,000 residential customers, while only 9 percent of municipal utilities have more than 20,000 residential customers. Thus, the referenced literature suggests that investor-owned utilities operate at a more efficient scale than municipal utilities.

Storm damages are normalized by dividing real damages (destruction of private and public property) by real personal income in 2000 in the counties covered by the utility. The average normalized damages for 1996-2002 were highest for cooperatives and lowest for investor-owned utilities, while in 2003-12 they were highest for investor-owned utilities and lowest for municipal utilities. Thus, there appears to be quite a bit of variability in which ownership types suffer the most storm damages. Within ownership types, there is also large variation in which utilities suffer the most damages; for example, the standard deviation of yearly damages for municipal utilities in 1996-2002 is more than 6 times larger than its mean. The subsample is similar to the full sample. Nonetheless, municipal utilities in the subsample tend to be larger, have more underground lines, be located in larger cities, and have lower levels of damages in 1996-2002 compared with municipal utilities in the full sample. More importantly, Table 3 indicates that municipal utilities spend the most on operations and maintenance of their dis- 
Table 3

Summary Statistics for the Expenditure Sample, 1995-2002

\begin{tabular}{|c|c|c|c|}
\hline & \multicolumn{3}{|c|}{ Investor } \\
\hline & Municipal & Owned & Cooperative \\
\hline \multicolumn{4}{|l|}{ Full sample: } \\
\hline$N$ & 1,437 & 179 & 801 \\
\hline Distribution miles & $\begin{array}{c}312 \\
(937)\end{array}$ & $\begin{array}{c}16,240 \\
(22,754)\end{array}$ & $\begin{array}{c}2,495 \\
(1,739)\end{array}$ \\
\hline$\%$ Lines underground & $\begin{array}{c}13 \\
(19)\end{array}$ & $\begin{array}{c}20 \\
(18)\end{array}$ & $\begin{array}{c}10 \\
(12)\end{array}$ \\
\hline$>20,000$ Customers $(\%)$ & $\begin{array}{c}9 \\
(29)\end{array}$ & $\begin{array}{c}82 \\
(38)\end{array}$ & $\begin{array}{c}27 \\
(44)\end{array}$ \\
\hline People per square mile by county & $\begin{array}{c}209 \\
(465)\end{array}$ & $\begin{array}{c}355 \\
(993)\end{array}$ & $\begin{array}{c}82 \\
(112)\end{array}$ \\
\hline Customers per mile & $\begin{array}{c}62 \\
(69)\end{array}$ & $\begin{array}{c}38 \\
(25)\end{array}$ & $\begin{array}{c}9 \\
(49)\end{array}$ \\
\hline Residential (\%) & $\begin{array}{l}83 \\
(7)\end{array}$ & $\begin{array}{l}86 \\
(4)\end{array}$ & $\begin{array}{l}87 \\
(11)\end{array}$ \\
\hline Wages for trade, transportation, and utilities (\$) & $\begin{array}{c}40,679 \\
(10,422)\end{array}$ & $\begin{array}{c}47,668 \\
(10,526)\end{array}$ & $\begin{array}{l}40,875 \\
(8,476)\end{array}$ \\
\hline Yearly damages, 1994-2002 (\%) & $\begin{array}{c}.165 \\
(1.030)\end{array}$ & $\begin{array}{c}.082 \\
(.241)\end{array}$ & $\begin{array}{c}.234 \\
(1.132)\end{array}$ \\
\hline Yearly damages, 2003-12 (\%) & $\begin{array}{l}.165 \\
(.567)\end{array}$ & $\begin{array}{c}.302 \\
(1.463)\end{array}$ & $\begin{array}{l}.221 \\
(.938)\end{array}$ \\
\hline \multicolumn{4}{|l|}{ Sample with distribution expenditures: } \\
\hline$N$ & 600 & 149 & 447 \\
\hline Distribution expenditures per mile (\$) & $\begin{array}{c}12,743 \\
(20,299)\end{array}$ & $\begin{array}{c}4,031 \\
(3,350)\end{array}$ & $\begin{array}{c}6,011 \\
(96,615)\end{array}$ \\
\hline Distribution miles & $\begin{array}{c}602 \\
(1,328)\end{array}$ & $\begin{array}{c}18,412 \\
(23,494)\end{array}$ & $\begin{array}{c}2,615 \\
(1,794)\end{array}$ \\
\hline$\%$ Lines underground & $\begin{array}{c}18 \\
(20)\end{array}$ & $\begin{array}{c}21 \\
(19)\end{array}$ & $\begin{array}{c}11 \\
(13)\end{array}$ \\
\hline$>20,000$ Customers $(\%)$ & $\begin{array}{c}22 \\
(41)\end{array}$ & $\begin{array}{c}91 \\
(28)\end{array}$ & $\begin{array}{c}27 \\
(44)\end{array}$ \\
\hline People per square mile by county & $\begin{array}{c}298 \\
(588)\end{array}$ & $\begin{array}{c}395 \\
(1,073)\end{array}$ & $\begin{array}{c}81 \\
(102)\end{array}$ \\
\hline Customers per mile & $\begin{array}{c}59 \\
(58)\end{array}$ & $\begin{array}{l}37 \\
(25)\end{array}$ & $\begin{array}{c}10 \\
(65)\end{array}$ \\
\hline Residential (\%) & $\begin{array}{l}83 \\
(8)\end{array}$ & $\begin{array}{l}87 \\
(3)\end{array}$ & $\begin{array}{l}87 \\
(11)\end{array}$ \\
\hline Wages for trade, transportation, and utilities (\$) & $\begin{array}{c}42,982 \\
(12,375)\end{array}$ & $\begin{array}{l}48,456 \\
(9,074)\end{array}$ & $\begin{array}{l}40,973 \\
(8,169)\end{array}$ \\
\hline Yearly damages, 1994-2002 (\%) & $\begin{array}{l}.105 \\
(.579)\end{array}$ & $\begin{array}{c}.082 \\
(.247)\end{array}$ & $\begin{array}{c}.239 \\
(1.148)\end{array}$ \\
\hline Yearly damages, 2003-12 (\%) & .156 & .340 & .207 \\
\hline
\end{tabular}

Data sources. Federal Energy Regulatory Commission, Form 1-Electric Utility Annual Report: Data (Current and Historical) (https://www.ferc.gov/docs-filing/forms/form-1/data.asp); Energy Information Administration, Form EIA-412 Archive Data (https://www.eia.gov/electricity/data /eia412/); Giles and Hayes (1999). Yearly damages for 1994-2012 are from National Oceanic and Atmospheric Administration (2014).

Note. Data are means, with standard deviations in parentheses. The utility-mean value of each variable is computed for 1995-2002 to form a single cross section. 
tribution network, while investor-owned utilities have the highest percentage of distribution lines underground.

Table 4 provides summary statistics for the power usage sample. Investorowned utilities tend to be the largest, while cooperatives tend to be the smallest, regardless of whether I measure the size of a utility by residential electricity consumption, nonresidential electricity consumption, the number of residential customers, or the total population in the counties served by the utility. For instance, the average investor-owned utility has 410,502 residential customers, while the average cooperative has 35,777 residential customers. Further, investorowned utilities self-generate a much higher percentage of the electricity they sell, compared with municipal utilities (43 percent versus 25 percent). Table 4 also shows that cooperatives cover areas with much lower density than municipal and investor-owned utilities, namely, 94 inhabitants per square mile versus 407 and 380 , respectively.

Nonetheless, municipal, investor-owned, and cooperative utilities cover similar areas in terms of income per capita and residential electricity consumption per customer. Income per capita is $\$ 35,306-\$ 36,868$, while the average residential customer purchases $42 \mathrm{~kW}$ of electricity per day. The average value of a detached house is similar in areas covered by municipal and investor-owned utilities $(\$ 136,082$ versus $\$ 129,573$ ) but lower in areas covered by cooperatives $(\$ 115,846)$. Despite the similar incomes, retail sales vary by mode of ownership; retail sales are $\$ 28$ per capita and day in areas served by an investor-owned utility versus $\$ 36$ in areas served by a cooperative. These differences may be due to the proxy for retail sales, which for most states is taxable sales. Thus, ownership-type differences in taxable sales may be due to differences among states in which goods are taxed. Further, municipal, investor-owned, and cooperative utilities cover areas with different weather patterns. Cooperative and investor-owned utilities experience more extreme weather (18 degree days versus 16 for municipal utilities). I construct the sample of utilities in a way that ensures that they had similar storm damages in 1996-98. However, over the sample period (1999-2012), investor-owned utilities covered areas with the highest level of storm damages, while municipal utilities covered areas with the lowest level of damages.

\section{Results}

\subsection{Expenditure Sample}

Table 5 presents the results of regressions of the logarithm of operations and maintenance distribution expenses (per mile of distribution line) on indicator variables for ownership type, with cooperative ownership as the excluded category. Municipal utilities spend $1.961-1.055 \approx 91$ percent more per mile than investor-owned utilities. Some of the differences in cost may be due to the fact that municipal utilities serve more densely populated areas, where maintaining the distribution network is inherently more expensive. For this reason, I reestimate the regression with additional controls for the log of the number of custom- 
Table 4

Summary Statistics for the Power Usage Sample, 1999-2012

\begin{tabular}{|c|c|c|c|}
\hline & & Investor & \\
\hline & Municipal & Owned & Cooperative \\
\hline Residential sales (Mw/day) & 3,625 & 11,371 & 1,348 \\
\hline & $(6,410)$ & $(18,711)$ & $(1,559)$ \\
\hline Self-generated (\%) & 25 & 43 & 5 \\
\hline & (34) & (35) & (19) \\
\hline Nonresidential sales (Mw/day) & 5,787 & 18,710 & 1,449 \\
\hline & $(8,986)$ & $(28,411)$ & $(2,737)$ \\
\hline Residential customers & 116,249 & 410,502 & 35,777 \\
\hline & $(217,455)$ & $(692,510)$ & $(35,891)$ \\
\hline Population of county & 817,039 & $1,908,066$ & 452,815 \\
\hline & $(1,591,849)$ & $(2,943,544)$ & $(571,213)$ \\
\hline People per square mile by county & 407 & 380 & 94 \\
\hline & (611) & $(1,229)$ & (144) \\
\hline Income per capita by county & 36,329 & 36,868 & 35,306 \\
\hline & $(7,351)$ & $(7,802)$ & $(7,438)$ \\
\hline Average house value by county & 136,082 & 129,573 & 115,846 \\
\hline & $(57,595)$ & $(64,209)$ & $(43,034)$ \\
\hline Residential sales (kW per capita/ & & & \\
\hline customer/day) & 42 & 42 & 42 \\
\hline & (29) & (31) & (26) \\
\hline Retail sales (per capita/day) (\$) & 33 & 28 & 36 \\
\hline & (13) & (11) & (14) \\
\hline Monthly damages (\% of personal & & & \\
\hline income) & .004 & .017 & .012 \\
\hline & $(.131)$ & $(.985)$ & $(.341)$ \\
\hline Monthly damages, $1996-98$ (\% of & & & \\
\hline personal income) & .003 & .004 & .003 \\
\hline & $(.004)$ & $(.006)$ & $(.004)$ \\
\hline Heating and cooling degree days & 16 & 18 & 18 \\
\hline & (11) & (12) & (13) \\
\hline
\end{tabular}

Data sources. Federal Energy Regulatory Commission, Form 1-Electric Utility Annual Report: Data (Current and Historical) (https://www.ferc.gov/docs-filing/forms/form-1/data.asp); Energy Information Administration, Form EIA-412 Archive Data (https://www.eia.gov/electricity/data/eia412/); Giles and Hayes (1999).

Note. Standard deviations are in parentheses.

ers per line mile, the log of the percentage of electric customers that are residential, the log of the population density, and the log of county wages in the sector of trade, transportation, and utilities. As expected, distribution expenditures are higher for utilities with more customers per distribution line mile. Nonetheless, even with these controls, I find that municipal utilities spend .035 - $(-.438) \approx$ 47 percent more per mile than investor-owned utilities.

A more direct way of controlling for utility size is to restrict the sample to investor-owned, municipal, and cooperative utilities that are roughly the same size. In Table 6, I regress the logarithm of operations and maintenance distribution expenses for utilities on the basis of size. The table includes $p$-values for the 


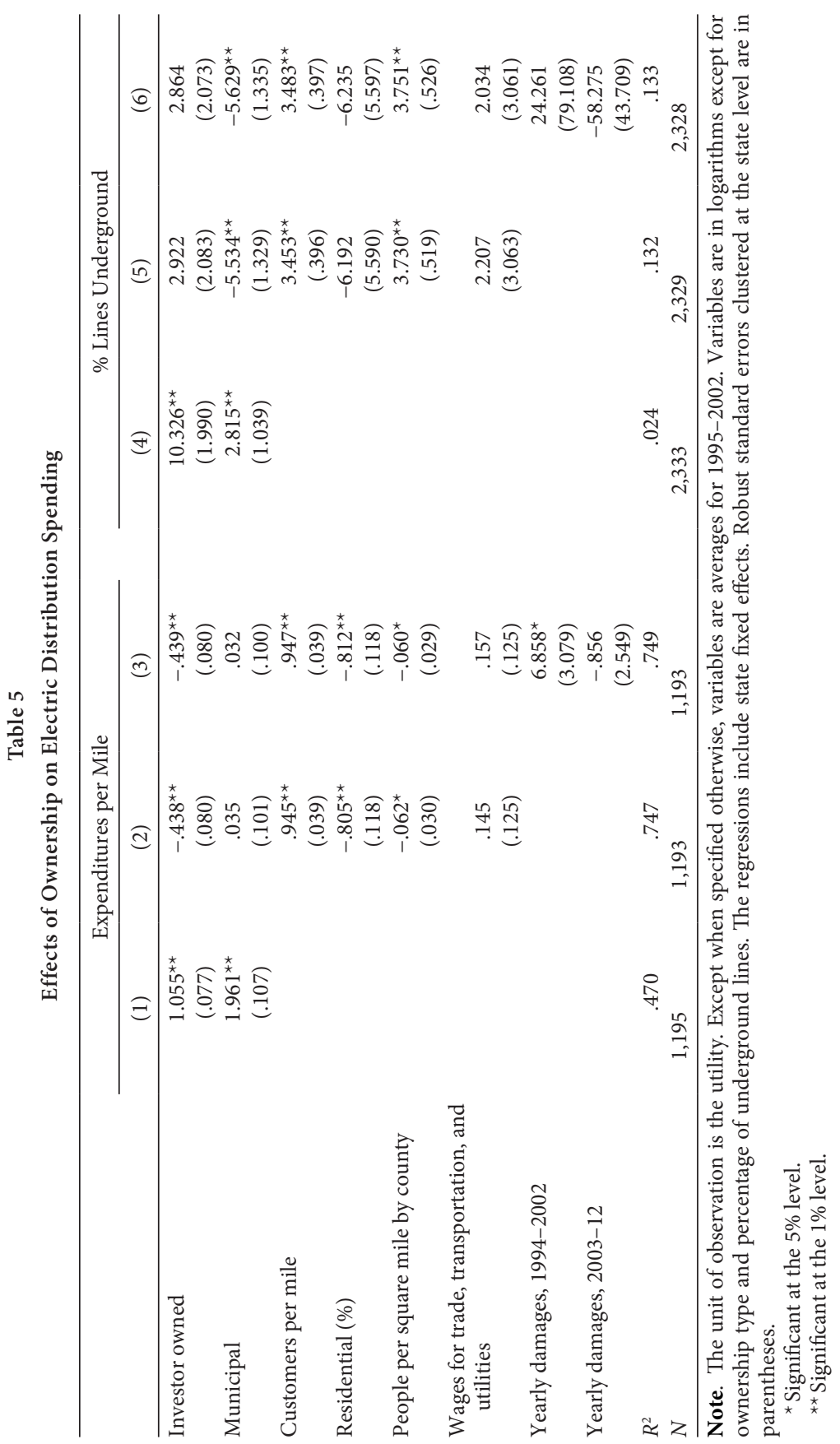

This content downloaded from 128.042.192.107 on May 01, 2017 10:22:08 AM All use subject to University of Chicago Press Terms and Conditions (http://www.journals.uchicago.edu/t-and-c). 


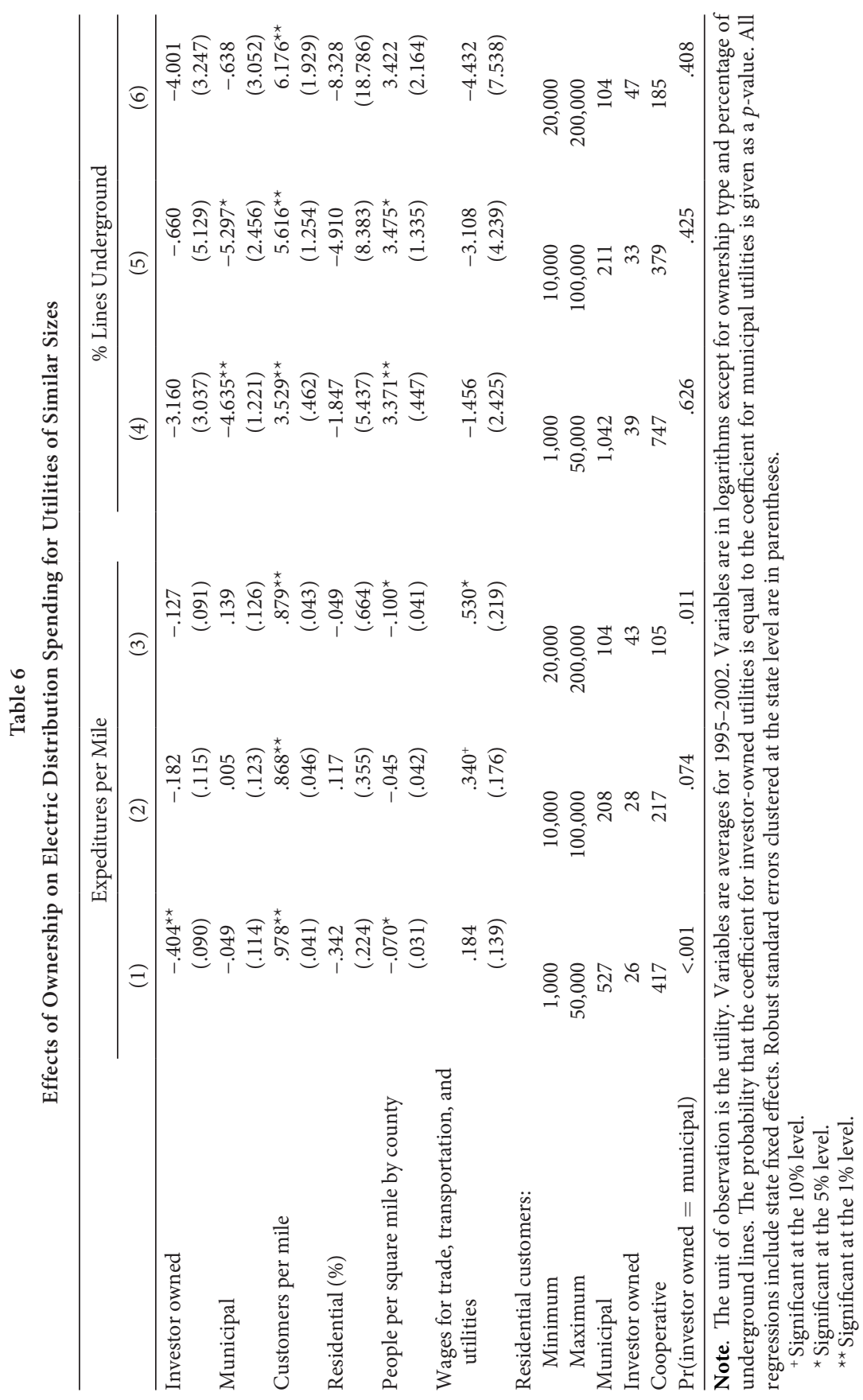

This content downloaded from 128.042.192.107 on May 01, 2017 10:22:08 AM All use subject to University of Chicago Press Terms and Conditions (http://www.journals.uchicago.edu/t-and-c). 
test that investor-owned utilities spend the same as municipal utilities. For the three samples, I can reject this hypothesis with $p$-values of $<.001, .074$, and .011 .

The higher distribution expenses may be due to the fact that municipal utilities faced more storms in the sample period. In 1994-2002, areas covered by municipal utilities in the expenditure sample had 28 percent higher levels of storm damages than areas covered by investor-owned utilities (see Table 3 ). However, in a utility's income statement, storm damages are classified as extraordinary expenses and thus are not included in the measure of operations and maintenance expenses. Nonetheless, it is possible that municipal utilities spend more on distribution maintenance because they are in areas that have greater storm activity. There are two reasons why this explanation is not sufficient to explain the higher maintenance expenditures by municipal utilities. First, in 2003-12, damage levels in areas covered by investor-owned utilities were 118 percent higher than in areas covered by municipal utilities (see Table 3 ). Thus, while it is clear that storm damages are highly volatile, municipal utilities in the expenditure sample do not appear to be located in areas with greater propensities to suffer storm damages. Second, I reestimate the regression with storm damages in 1994-2002 and 200312 as additional control variables. Even with these controls, I find that municipal utilities spend $.032-(-.439)=47$ percent more per mile on distribution than investor-owned utilities (see Table 5).

I estimate the same type of regressions with the percentage of distribution lines underground as the dependent variable. Investor-owned utilities have 8 percent more distribution lines underground (thus almost twice the percentage of distribution lines underground) as municipal utilities. Further, utilities in more densely populated areas have a higher percentage of their distribution lines underground. However, the results for the subsamples in Table 6 do not indicate that investor-owned utilities bury more lines underground. Thus, the ownershiptype difference in the percentage of lines underground may be purely an artifact of increasing returns to scale rather than ownership structure.

In summary, my results support newspaper accounts that claim that municipal utilities spend more on maintenance of distribution lines than do investor-owned utilities. However, my results also indicate that municipal utilities are not necessarily better prepared for storms, since they have a smaller percentage of their distribution lines underground, perhaps because of their smaller size.

\subsection{Power Usage Sample}

To estimate the overall effect of storm preparedness on quality of service, I examine changes in electricity consumption that follow major storms. I estimate three regressions of the following form:

$$
\Delta \ln q_{u s y t}=\alpha_{y}^{1}+\alpha_{s}^{2}+\alpha_{o(u)}^{3}+\sum_{m=-1}^{1} \beta_{o(u)}^{m} \Delta \text { Damages }_{u s y t-m}+\gamma_{s} \Delta \ln d_{u s y t},
$$

with residential electricity consumption per customer, retail sales, and employ- 


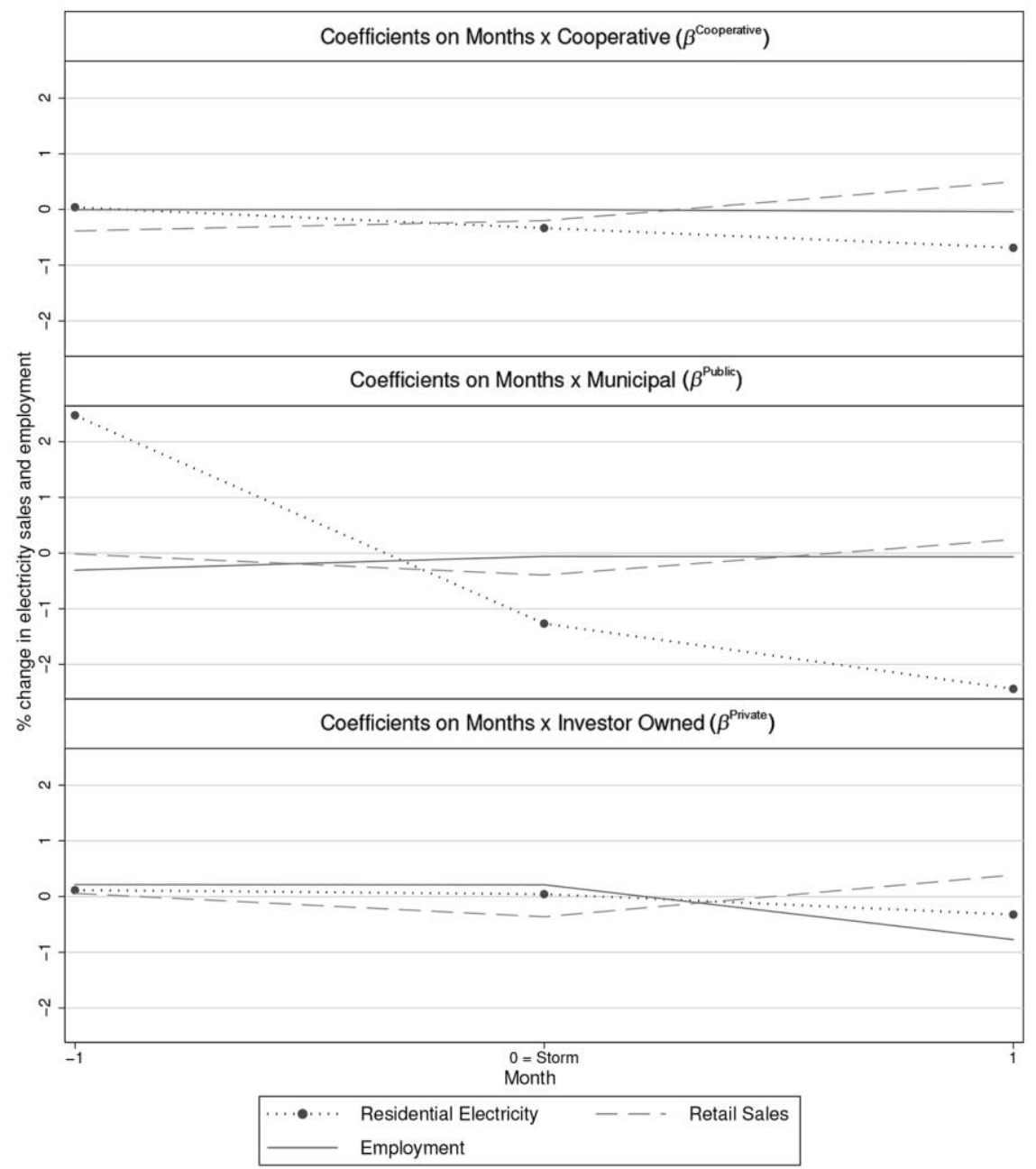

Figure 3. Effects of a major storm

ment as the dependent variable $\left(q_{\text {usyt }}\right)$. Thus, I include the current value of damages as well as a lag and a lead. These variables are interacted with the mode of ownership of the utility. For instance, when the dependent variable is residential electricity consumption, the coefficients $\beta_{-1}^{\text {Public }}, \beta_{0}^{\text {Public }}$, and $\beta_{1}^{\text {Public }}$, describe the percentage changes in electricity consumption by a municipal utility that occur the month before the storm, the month of the storm, and the month after. These coefficients are plotted in Figure 3 and provide evidence of my main result.

Residential electricity consumption for municipal utilities declines by 1.2-2.4 percent the month of the storm and the following month. For investor-owned utilities, electricity consumption declines by .3 percent the month after the storm. 
Finally, electricity consumption for cooperatives decreases by .3-.6 percent the month of the storm and the following month. Decreases in employment are small in magnitude for cooperatives and municipal utilities (.0001-.07 percent) but larger for investor-owned utilities (.8 percent the month after the storm). Finally, retail consumption declines slightly the month of the storm and then recovers the following month.

Thus, a major storm is most likely to reduce electricity sales in areas covered by municipal utilities. Further, this reduction appears to be due to a change in the supply of electricity rather than a change in demand since reductions in employment and retail sales are of small magnitude.

Table 7 reports these results in regression format, in which Damages is the sum of storm damages the month of the storm and the following month. To simplify the table, I do not include a full lag structure.

Storm damages of 1 percent of personal income are associated with a .07 percent decrease in residential electricity consumption the month of the storm and the following month. When I interact damages with the mode of ownership, I find that storm damages of 1 percent of personal income reduce residential electricity consumption for municipal utilities by $.51+1.34=1.85$ percent but have no effect on residential electricity consumption for investor-owned utilities. Storm damages of 1 percent of personal income also reduce nonresidential electricity consumption for municipal utilities by .7 percent but have no effect on nonresidential consumption for investor-owned utilities.

These results may be driven by decreases in electricity demand following a storm. It is possible that demand decreases by a greater amount in areas served by municipal utilities, compared with areas served by investor-owned utilities. I attempt to address this concern by examining the effect of storm damages on retail sales and employment. When I estimate equation (3) with retail sales and employment as the dependent variables, I do not find a statistically significant decrease in these variables following a storm in areas served by municipal utilities. This suggests that the decline in electricity sales in areas served by municipal utilities is not driven by ownership-type differences in changes in electricity demand.

I argued that ownership type was determined in the past and should be most closely correlated with past rather than contemporaneous county-level characteristics. This suggests the use of past municipal ownership as an instrument for current municipal ownership. For municipal utilities, my instrument is an indicator variable for whether the utility is listed in Federal Power Commission (1946). For investor-owned utilities and cooperatives, the instrument is the fraction of their residential customers who live in cities that had a municipal utility in $1946 .^{30}$ The

\footnotetext{
${ }^{30}$ I examined all cities that had a municipal utility in 1946 and had a population of at least 2,000 in 2000. I then determined the electric utility provider for that city and used this information to determine the percentage of an investor-owned utility's or cooperative's residential customers that were served by a municipal utility in 1946. For instance, the Central Louisiana Electric Company provides electricity to Opelousas, which in 2000 had a population of 22,860 and had a municipal utility in 1946. Since the Central Louisiana Electric Company has 200,000 residential customers and, on average, there are 2.52 individuals per residential customer, the percentage of its customers that used to be served by a municipal utility is $2.52 \times 22,860 / 200,000$.
} 


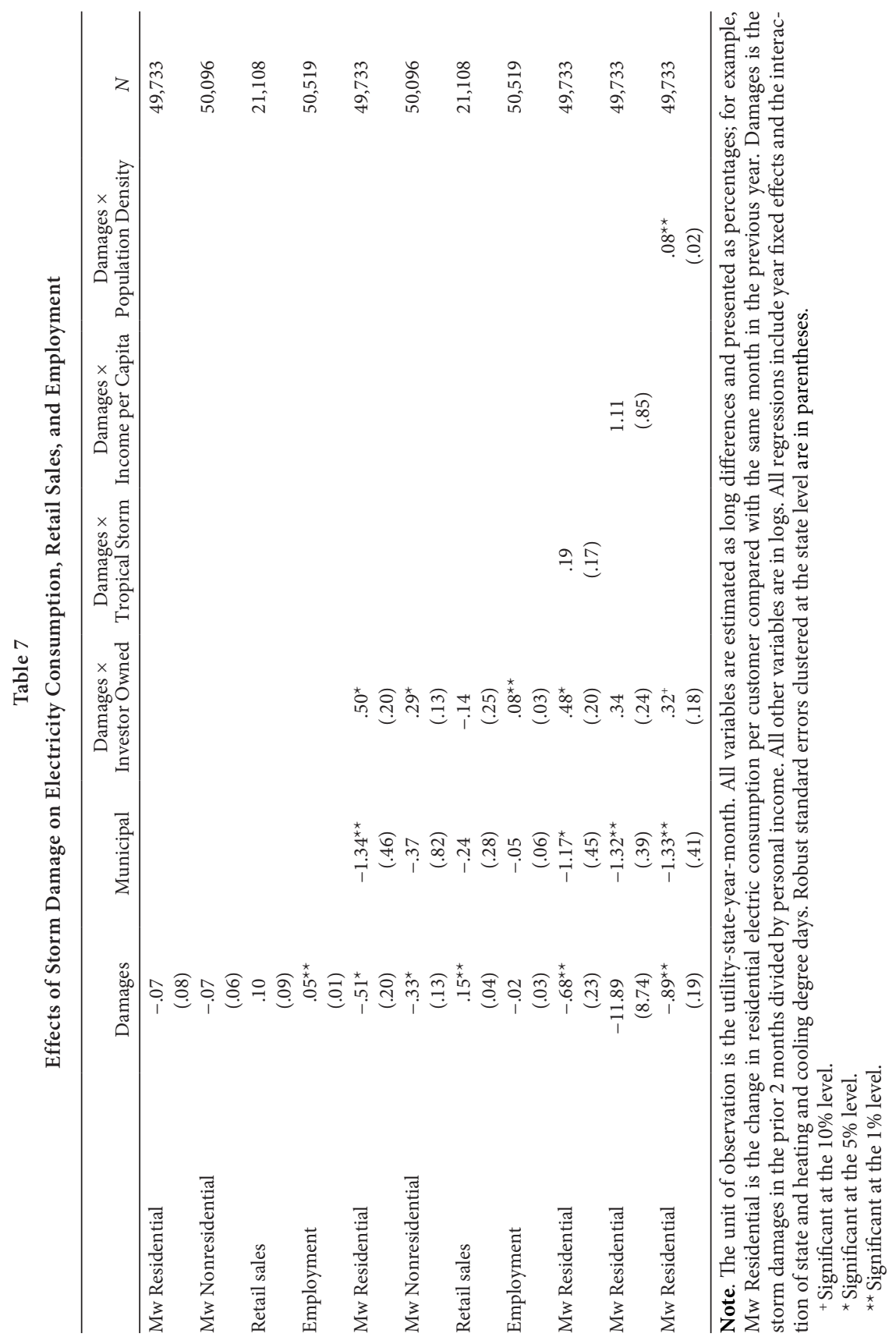

This content downloaded from 128.042.192.107 on May 01, 2017 10:22:08 AM All use subject to University of Chicago Press Terms and Conditions (http://www.journals.uchicago.edu/t-and-c). 
instrumental variables estimates are similar to my prior findings: storm damages of 1 percent of personal income reduce residential sales for municipal utilities by $.48+1.57=2.05$ percent. Further, ownership type in the past strongly correlates with current ownership type, as demonstrated by a first-stage F-statistic of 274. The results in Tables 5 and 6 also remain unchanged when I use the instrumental variables approach.

Nonetheless, these results may still be driven by ownership-type differences in storm damages. I attempt to address this concern by excluding utilities in areas that had unusually high levels of damages between 1996 and 1998 from the sample. To further address this concern, I control for damages caused by a tropical storm and interact damages with income per capita, population density, and the average value of a house. ${ }^{31}$ I find greater decreases in residential electricity consumption in more rural areas following a storm, but the other variables do not have statistically significant effects. Further, the inclusion of these variables does not qualitatively change the results.

To provide additional evidence that the results are not driven by a correlation between the nature of the storms and the mode of ownership, I reestimate the regressions excluding the observations of one state at a time. The magnitude of the coefficients is the largest if I exclude Tennessee and the smallest if I exclude Utah from the sample. Nonetheless, all 51 regressions give qualitatively the same findings.

\subsection{Additional Findings}

I find greater decreases in electricity consumption following major storms in areas served by municipal utilities. In this section, I examine whether these findings are driven by characteristics of municipal utilities other than their ownership type. The regressions in this section include the interaction between population density and storm damages, since I find this variable to affect changes in electricity consumption.

First, municipal utilities in the sample are smaller than investor-owned utilities (see Table 4). It is possible that larger utilities are better at dealing with storms; for instance, they may use crews from unaffected areas to restore electricity service in the affected areas. If this is the case, the poor performance of municipal utilities may be due to their size rather than a lack of managerial incentives. For this reason, Table 8 examines the impact of storms on residential electricity consumption using the interaction of storm damages and the log of lagged yearly residential electricity consumption. The inclusion of this additional variable does not qualitatively affect the results.

A more direct way to control for utility size is to restrict the sample to investorowned, municipal, and cooperative utilities that are roughly the same size. In Table 9, I estimate the impact of storm damages on residential electricity consumption for utilities that have 1,000-50,000 residential customers and obtain similar

\footnotetext{
${ }^{31}$ To conserve space, the regression with housing values is not included in Table 7.
} 


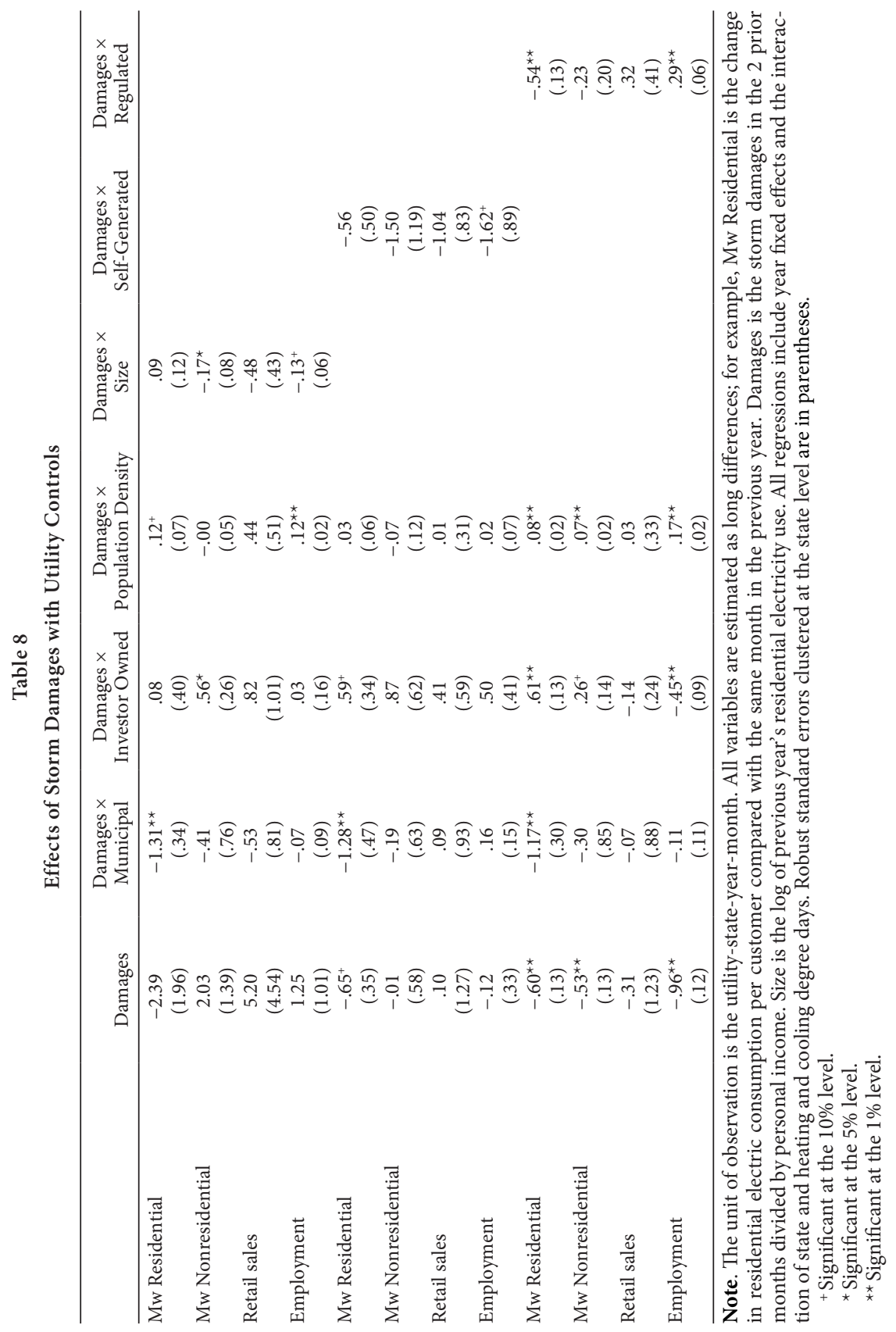

This content downloaded from 128.042.192.107 on May 01, 2017 10:22:08 AM All use subject to University of Chicago Press Terms and Conditions (http://www.journals.uchicago.edu/t-and-c). 
results. I also obtain similar results when I restrict the sample to utilities with 10,000-100,000 residential customers or 20,000-200,000 residential customers. When controlling for utility size, I must take into account that municipal utilities are located in areas that experience greater decreases in electricity demand following a storm. For this reason, I examine the effect of storm damages on retail sales for the three different utility sizes. In all three subsamples, the changes in retail sales in areas with municipal utilities are not significantly different from those in areas with investor-owned utilities. ${ }^{32}$

Second, utilities differ in whether they generate or buy the electricity they distribute. Investor-owned utilities self-generate a higher fraction of the power they sell, compared with municipal utilities. Thus, the better storm-related performance of investor-owned utilities could be explained by a greater control of their electricity supply. For this reason, in Table 8, I estimate the impact of storms on residential electricity consumption using the interaction of storm damages and the percentage of electricity that is self-generated. The coefficient for this additional variable is statistically insignificant, and its inclusion does not qualitatively affect the results.

A more direct way to control for the degree of vertical integration is to split the sample into utilities that purchase all their electricity and those that self-generate some of their electricity. For utilities that purchase all their electricity (pure distribution), I find that storm damages amounting to 1 percent of personal income reduce municipal utilities' residential electricity consumption by $.53+2.73=$ 3.26 percent but have no effect on investor-owned utilities (see Table 10). For utilities that generate some of their electricity (vertical integration), I do not find any differences in changes in electricity consumption between municipal and investor-owned utilities. Because I must take into account that these results are due to differences in changes in electricity demand, I examine the effect of storm damages on retail sales for pure-distribution utilities and for vertically integrated utilities. The coefficient estimates suggest that demand effects cannot explain the entire decrease in electricity consumption in areas served by municipal utilities that purchase all their electricity. ${ }^{33}$

Third, not all states regulate municipal utilities. Thus, the worse performance of municipal utilities may be due to lack of regulatory control. Alternatively, regulation may worsen storm preparedness, and the performance of municipal utilities might be even worse if they were all regulated. ${ }^{34}$ For this reason, I estimate the impact of storms on residential electricity consumption using the interaction

\footnotetext{
${ }^{32}$ For instance, for utilities with $1,000-50,000$ customers, the change in retail sales is -1.27 percent for municipal utilities and -.79 percent for investor-owned utilities. These numbers are not statistically different from one another $(p$-value $=.5)$.

${ }^{33}$ Note that the coefficient estimates for cooperatives are very large in magnitude. However, these results are based on the very small number of vertically integrated cooperatives for which I have retail sales information.

${ }^{34}$ For instance, Connecticut Light and Power's lack of preparedness for Hurricane Irene and the October nor'easter was blamed on the state regulatory agency's failure to authorize enough funding for vegetation management (Davies Consulting 2012).
} 


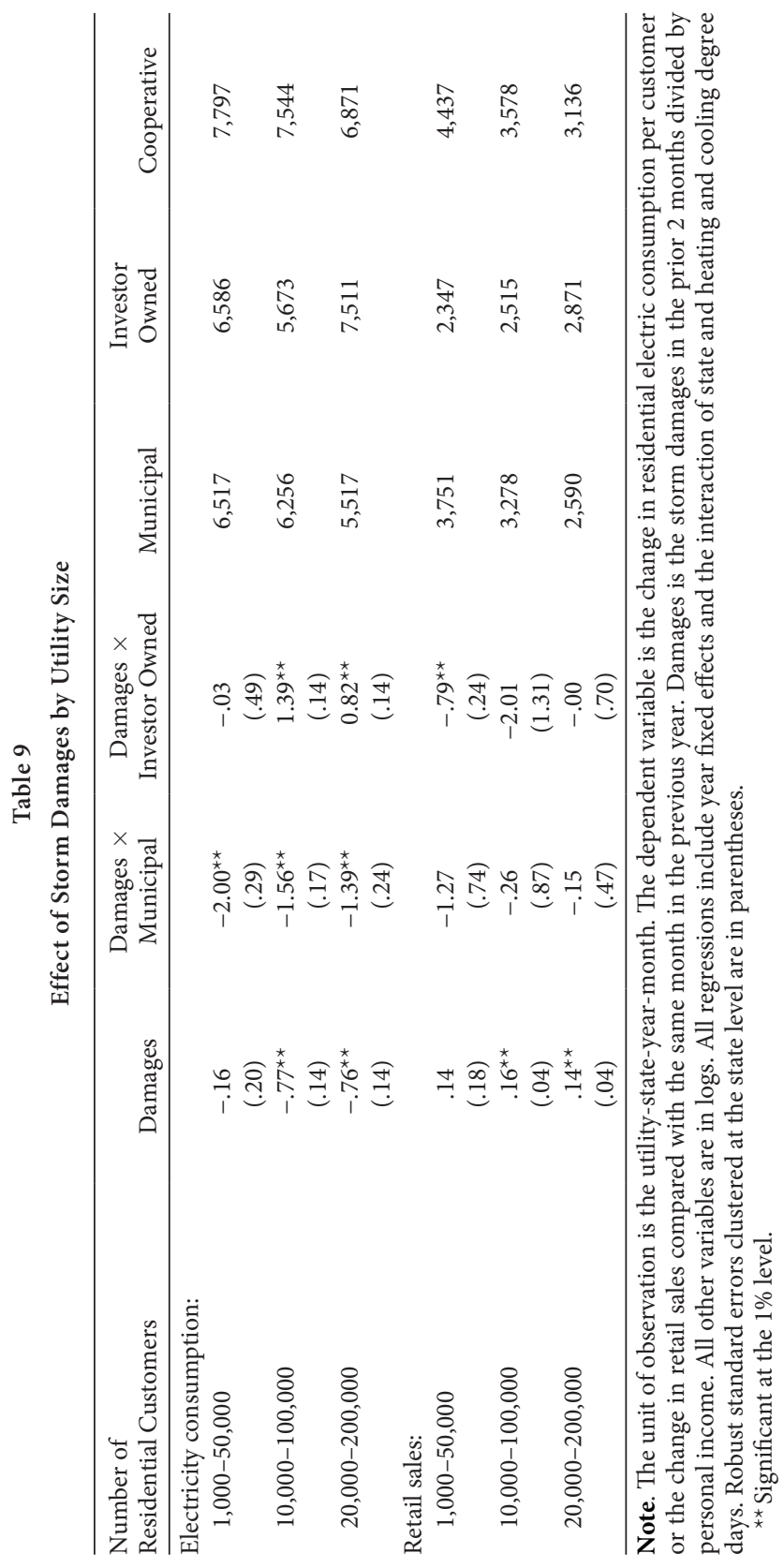

468

This content downloaded from 128.042.192.107 on May 01, 2017 10:22:08 AM All use subject to University of Chicago Press Terms and Conditions (http://www.journals.uchicago.edu/t-and-c). 


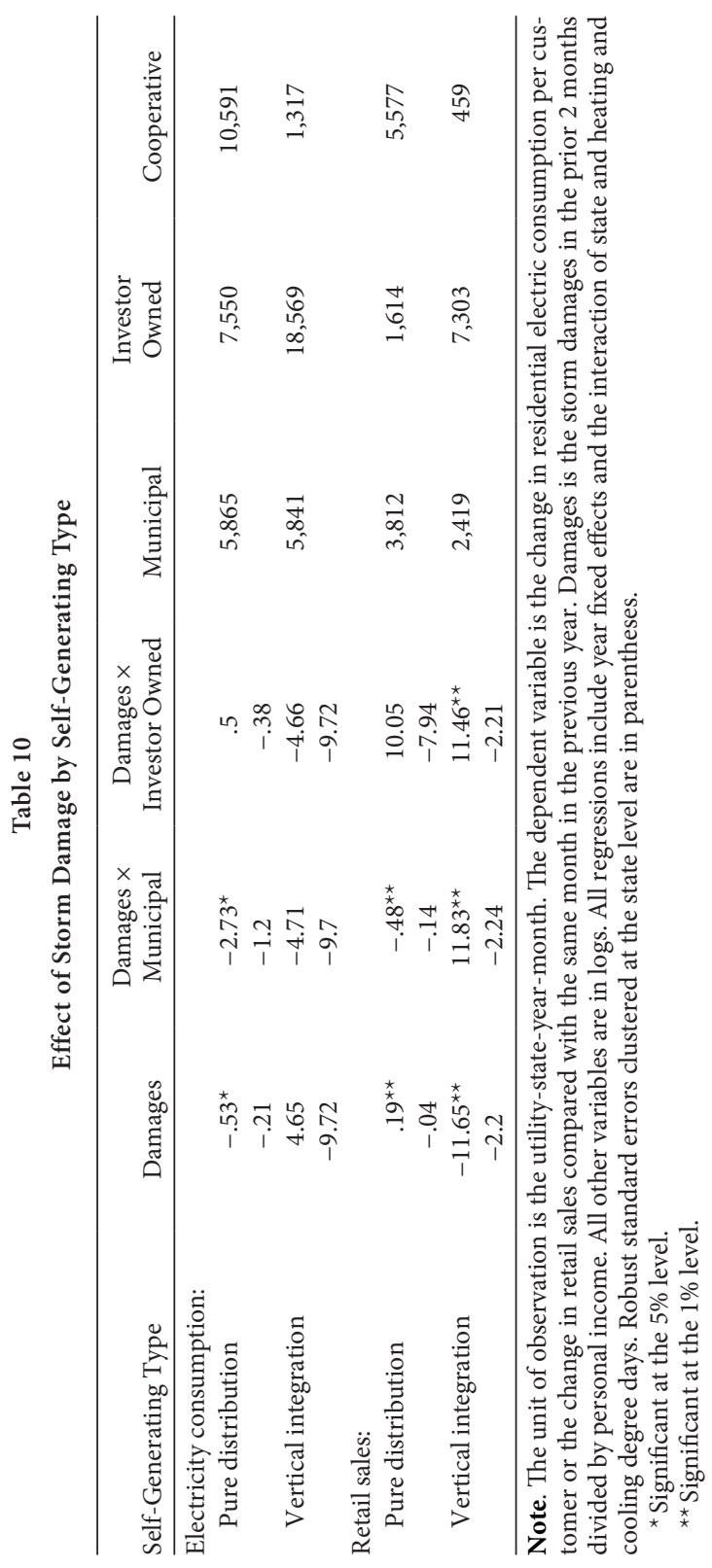

469

This content downloaded from 128.042.192.107 on May 01, 2017 10:22:08 AM All use subject to University of Chicago Press Terms and Conditions (http://www.journals.uchicago.edu/t-and-c). 
of storm damages and an indicator for whether the utility is subject to the state regulatory commission. Even with this additional variable, I find a greater decrease in electricity consumption in areas covered by municipal utilities (Table 8). Further, I find greater reductions in electricity consumption in areas served by municipal uilities following a storm when states regulate municipal utilities (versus when states do not regulate municipal utilities).

The greater decrease in electricity consumption in states with regulation may be due to demand rather than supply effects. For instance, electricity demand may decrease by a greater amount in states that regulate municipal utilities if they are more likely to issue mandatory evacuations before a storm. For this reason, I reestimate the same regression with retail sales and employment as the dependent variables. I find that employment decreases less in states that regulate municipal utilities and find no difference in changes in retail sales across regulatory types (Table 8). ${ }^{35}$ Thus, the effect of regulation on electricity consumption is most likely to be a supply effect; that is, regulated municipal utilities are more likely than nonregulated municipal utilities to have outages following storms.

\section{Conclusion}

Alleged lack of storm preparation by investor-owned utilities has led to popular support for an expansion of municipal electrical services following the 1998 ice storm in upstate New York, Hurricane Irene, and Superstorm Sandy (Singer 2012; Cardwell 2013; Bruun 2009; Janoski 2012). I examined spending on the distribution system for a sample of 179 investor-owned, 801 cooperative, and 1,437 municipal utilities in the United States for 1995-2002. Compared with investorowned utilities, municipal utilities spend more on maintenance of distribution lines but have a smaller fraction of them underground. Thus, there are several reasons why municipal utilities' higher maintenance expenditures need not lead to greater storm preparedness. First, investor-owned utilities have a higher percentage of lines underground. Second, the higher distribution expenses may be evidence of wasteful spending by municipal utilities rather than better maintenance. Third, the higher distribution expenses of municipal utilities could be evidence that they are too small to benefit from economies of scale.

To examine empirically which utilities have the best performance in response to major storms, I examined a stratified random sample of 241 investor-owned, 96 cooperative, and 94 municipal utilities in the United States for 1999-2012. I provided evidence that electricity consumption decreases more when the utility is municipally owned. Thus, the evidence contradicts one of the justifications for calls to expand municipal electrical service, namely, the alleged better performance of municipal utilities during storms. Prior international evidence reaches a similar conclusion, namely, that the privatization of the electric distribution network does not lead to more power outages (Fumagalli, Garrone, and Grilli

\footnotetext{
${ }^{35}$ For instance, the change in employment in municipal utilities that are regulated is $-.96-.11$ $+.29=-.78$ percent.
} 
2007; Gonzalez-Eiras and Rossi 2007; Hartley 1999). The political process is one potential source of government inefficiency. For instance, Boylan (2015) provides evidence that the pay for employees in municipal utilities increases the year of a mayoral election. Nonetheless, these findings do not necessarily indicate that investor-owned utilities are preferable, since prior studies show that municipal electric utilities in the United States charge lower prices, even when accounting for subsidies (Peltzman 1971; Kwoka 2002).

Methodologically, I provided a novel proxy to measure power outages: the difference between monthly electricity consumption and the previous year's monthly electricity sales. To validate the measure, I found it to be correlated with outages recorded on the Department of Energy's form Form OE-417. I also compared changes in monthly electricity sales after a storm to changes in monthly employment and monthly retail sales. I did not find electricity sales to move conjointly with retail sales and employment. Thus, changes in electricity sales are more likely to represent changes in the supply of electricity than changes in the demand of electricity. 

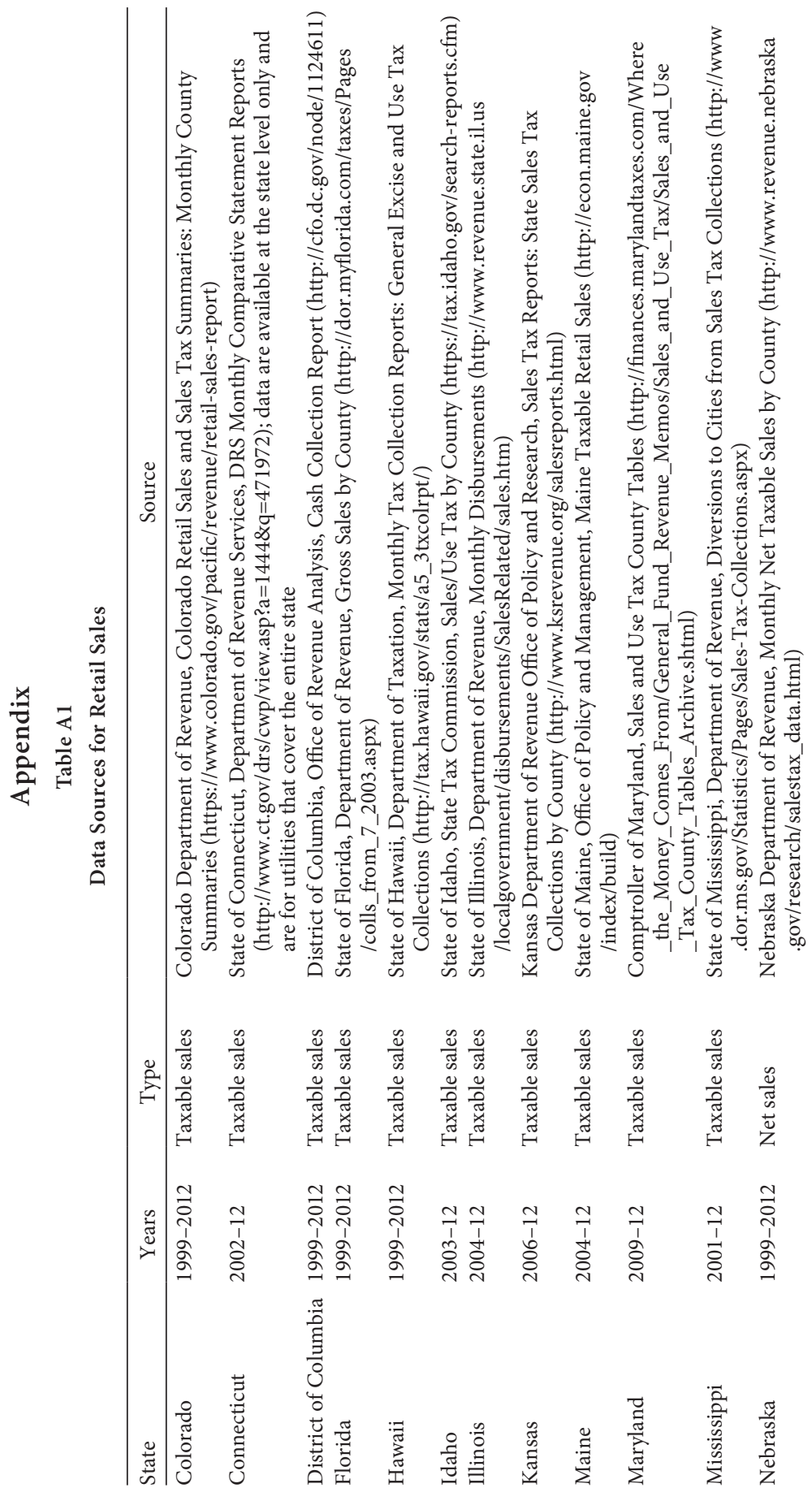

This content downloaded from 128.042.192.107 on May 01, 2017 10:22:08 AM All use subject to University of Chicago Press Terms and Conditions (http://www.journals.uchicago.edu/t-and-c). 


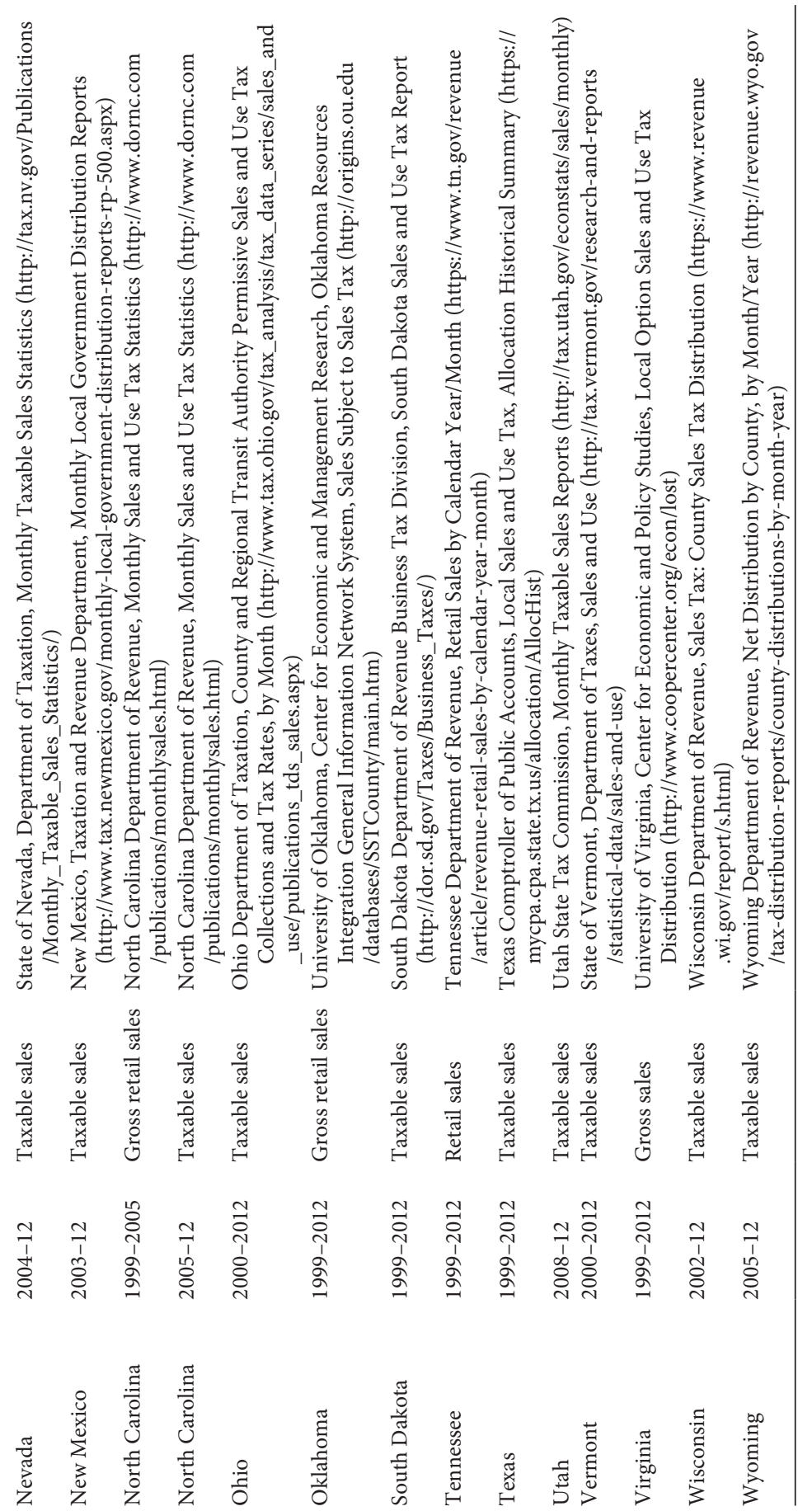

This content downloaded from 128.042.192.107 on May 01, 2017 10:22:08 AM All use subject to University of Chicago Press Terms and Conditions (http://www.journals.uchicago.edu/t-and-c). 


\section{References}

Beecher, Janice A., G. Richard Dreese, and John D. Stanford. 1995. Regulatory Implications of Water and Wastewater Utility Privatization. Report No. NRRI 95-09. July. Columbus, OH: National Regulatory Research Institute.

Belasen, Ariel R., and Solomon W. Polachek. 2009. How Disasters Affect Local Labor Markets: The Effects of Hurricanes in Florida. Journal of Human Resources 44:251-76.

Boylan, Richard T. 2015. Is There a Deadweight Loss of Politics in Public Service Provision? Unpublished manuscript. Rice University, Department of Economics, Houston, TX.

Bruun, Matthew. 2009. Municipal Utilities Pondered after Storm Mess; Irate Customers Looking for Options. Worchester Telegram, January 11, p. A1.

Cardwell, Diane. 2013. Power to the People. New York Times, March 14, p. B1.

Cox, Rob. 2011. The Troubling Connecticut Power Failure. New York Times, November 3.

Davies Consulting. 2012. Final Report: Connecticut Light and Power's Emergency Preparedness and Response to Storm Irene and the October Nor'easter. Prepared for Northeast Utilities System. February 27. Chevy Chase, MD: Davies Consulting.

Doane, Michael J., and Daniel F. Spulber. 1997. Municipalization: Opportunism and Bypass in Electric Power. Energy Law Journal 18:333-61.

Downton, Mary W., J. Zoe Barnard Miller, and Roger A. Pielke, Jr. 2005. Reanalysis of U.S. National Weather Service Flood Loss Database. Natural Hazards Review 6:13-22.

Electric Information Agency. 2013. Electric Power Annual 2012. Washington, DC: Department of Energy.

Federal Power Commission. 1946. Directory of Electric and Gas Utilities in the United States, 1946. Washington, DC: Federal Power Commission.

Florida Public Service Commission. 1999-2011. Statistics of the Florida Electric Utility Industry. Tallahassee: Florida Public Service Commission.

Fumagalli, Elena, Paola Garrone, and Luca Grilli. 2007. Service Quality in the Electricity Industry: The Role of Privatization and Managerial Behavior. Energy Policy 35:6212-24.

Giles, Ellen Flynn, and Ann T. Hayes, eds. 1999. McGraw-Hill Energy Directory of Electric Power Producers and Distributors 2000. 108th ed. New York: McGraw-Hill.

Glaeser, Edward L. 2004. Public Ownership in the American City. Pp. 130-62 in City Taxes, City Spending: Essays in Honor of Dick Netzer, edited by Amy Ellen Schwartz. Northampton: Edward Elgar.

Gonzalez-Eiras, Martín, and Martín A. Rossi. 2007. The Impact of Electricity Sector Privatization on Public Health. Research Network Working Paper No. R-524. Inter-American Development Bank, Washington, DC.

Growitsch, Christian, Tooraj Jamasb, and Michael Pollitt. 2009. Quality of Service, Efficiency, and Scale in Network Industries: An Analysis of European Electricity Distribution. Applied Economics 41:2555-70.

Hart, Oliver, Andrei Shleifer, and Robert W. Vishny. 1997. The Proper Scope of Government: Theory and an Application to Prisons. Quarterly Journal of Economics 112:112761.

Hartley, Peter. 1999. Reform of the Electricity Supply Industry. Economia Mexicana 8:4590.

Hausman, Catherine. 2014. Corporate Incentives and Nuclear Safety. American Economic Lournal: Economic Policy 6:178-206.

Janoski, Steve. 2012. Two Towns Want to Join Butler Utility after Company's Fast Storm 
Repairs. Bergen County Record, November 17, p. L03.

Jones, L. R. 1989. Assessing the Financial Feasibility of Municipal Electric Utility Formation. State and Local Government Review 21:38-46.

Kaufmann, Larry, Lullit Getachew, Matt Makos, and John Rich. 2010. System Reliability Regulation: A Jurisdictional Survey. Madison, WI: Pacific Economics Group.

Kwoka, John E., Jr. 2002. Governance Alternatives and Pricing in the U.S. Electric Power Industry. Lournal of Law, Economics, and Organization 18:278-94.

Levitt, Steven D. 1997. Using Electoral Cycles in Police Hiring to Estimate the Effect of Police on Crime. American Economic Review 87:270-90.

Lim, Claire S. H., and Ali Yurukoglu. 2014. Dynamic Natural Monopoly Regulation: Time Inconsistency, Asymmetric Information, and Political Environments. Unpublished manuscript. Cornell University, Department of Economics, Ithaca, NY.

Lopez-de-Silanes, Florencio, Andrei Shleifer, and Robert W. Vishny. 1997. Privatization in the United States. RAND Journal of Economics 28:447-71.

McCarthy, Kevin, and Lee R. Hansen. 2012. Forming a Municipal Electric Utility. Research Report No. 2012-R-0001. Hartford: Connecticut General Assembly Office of Legislative Research.

National Oceanic and Atmospheric Administration. 1978. Storm Data and Unusual Weather Phenomena with Late Reports and Corrections. Rockville, MD: National Climatic Data Center.

/stormevents/csvfiles/.

National Weather Service. 2007. Storm Data Preparation. Instruction No. 10-1605. Silver Spring, MD: National Weather Service.

Peltzman, Sam. 1971. Pricing in Public and Private Enterprises: Electric Utilities in the United States. Journal of Law and Economics 14:109-47.

Platts. 2006. 2007 Platts UDI Directory of Electric Power Producers and Distributors. London: Platts.

Rodgers, Paul, and Karon Bauer. 1991. 1990 Annual Report on Utility and Carrier Regulation of the National Association of Regulatory Utility Commissioners. Washington, DC: National Association of Regulatory Utility Commissioners.

Rose, Nancy L., and Paul L. Joskow. 1990. The Diffusion of New Technologies: Evidence from the Electric Utility Industry. RAND Iournal of Economics 3:354-73.

Salvanes, Kjell G., and S. Tjøtta. 1994. Productivity Differences in Multiple Output Industries: An Empirical Application to Electricity Distribution. Lournal of Productivity Analysis 5:23-43.

Schap, David. 1986. Municipal Ownership in the Electric Industry. New York: Praeger.

Sigo, Shelly. 2003. Voters in Winter Park, Fla., Approve $\$ 50 \mathrm{M}$ of Bonds to Buy Electrical Utility. Bond Buyer, September 11.

Singer, Stephen. 2012. Connecticut Eyes Utility System Changes. Berkshire Eagle, November 22 .

Strobl, Eric. 2011. The Economic Growth Impact of Hurricanes: Evidence from U.S. Coastal Counties. Review of Economics and Statistics 93:575-89.

Ter-Martirosyan, Anna, and John Kwoka. 2010. Incentive Regulation, Service Quality, and Standards in U.S. Electricity Distribution. Lournal of Regulatorv Economics 38:258-73.

Van Voorhis, Scott. 2012. Power Outages: Who Pays the Bill? Boston University, New England Center for Investigative Reporting, Boston. http://www.masspirg.org/media /map/necir-power-outages-who-pays-bill. 
Vlaicu, Razvan, and Alexander Whalley. 2013. Hierarchical Accountability in Government: Theory and Evidence. Unpublished manuscript. University of Maryland, Department of Economics, College Park.

Weiss, Ray. 2013. South Daytona, FPL Aiming to Repair Short-Circuited Relationship. Daytona Beach News-Journal, June 16.

Yatchew, A. 2000. Scale Economies in Electricity Distribution: A Semiparametric Analysis. Iournal of Applied Econometrics 15:187-210. 